でびりろこ1

あたの農とマ戦

るの労民はな後 吕力層、以是

た、㤎分今し本

といさ解日方農

えわか論に法村

ばゆれにい論に

るてした上つ

栗エきろるすい

原 た 、研主て

百湆こそ究要何

寿土之の加なが

はンは基ら関し

、言底明心か

次支 5 にらがの

の配をお方社

よ論まいで農会

うでたてあ村学

にあな農乃に的

言つ、村 5 お論

うた。支。け究

戦と学配共る峝支試

戦はさ実体配䚺

前周い態構る

に知、热㑷造ば

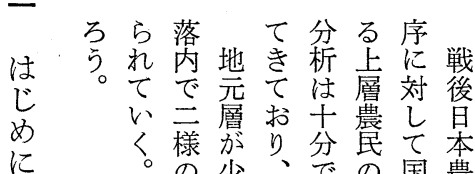

に

けの注握しにあ

けと貝に論あい

るこ老加っ 、

。の少、での国農

加支数基あ存家村

か配に本っ在独の

るルな的た方占支

支1つにと必資配

配卜てはは要本構

のがきムいと主造

広用てラえな義を

域意い支なるに論

化さる配い。よじ

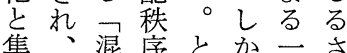

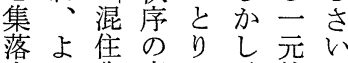

内 化変わ、的、

秩広し化けこ支注

序域農を一の配目

と化村過九理がを

のし度六論説あ

関た集に○唯吕び

連次落押年農れた

元 ᄂ 代村 も

おでで進以へ国の

よのはめ降農国に

たしれ主的き多もが齐醅き地業独工

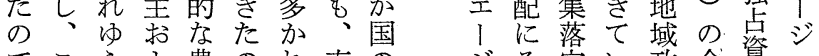

でこえよ農のれ直のジそ完い政全資工

あれ、び村で少接農热結る策般本ン

るま改小社あな的符

さ゚で草作会るが社

トぞ的㠵農支義支

支結配時政配あ配

。よに造が、地構

栗に拉变ま戦分詨造

原他七笂厄後的刘

論階は攵盐な尔終

諭階、方の主、作局

述級国、主制伝的

は它家別体の承農に

蓒農独個的解的民は

連禁点の打体なの資

配びはに孝にあ諭

今けはそ点ゆあ

星的今変は挍諸る。

在て旦华名機そ

様く可差村結に气

にく稼圶村繥結は

こそにも集杲びは 伝

いうなき落農い統

音支酚社よに社階本

彦を主構物も的関義

指共義造質な勢係に

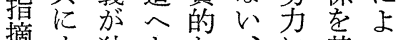

摘す独とな、に基っ

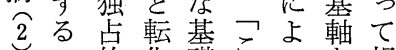

に学的化礎劣っと規

て手っわ概た的

検るてだ次集た便な 橋

討こきた元落便共

をとてせ染乗同本

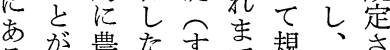

るが農たすすで賛、地れ

深でおてのリ得体

め地り、元諸 留者的

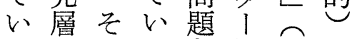

くののる增層栗么幸

らく者方わ地さ主な

必利ば。噴の原

要害あ出検支

がが、さ討で配

あ守集せ・秩

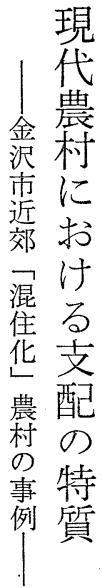

にっ握它地主て、号 
再そ彦うな中合ゆ的であしで国配本り用てかを理戦

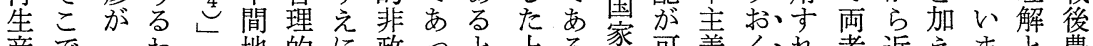
産で弓わに地的に政っと上る独可義くれ者近えまと農 さは官けに帯なで治た同層上独能のれ、ばの代て、い村 れ支僚でよに感あ华か時農層点た収た、门リ官お本うに

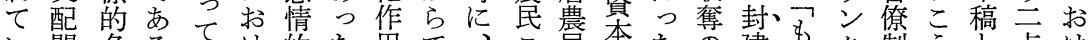

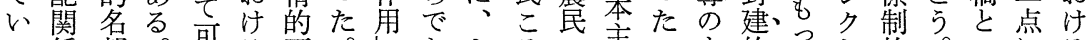
る係望。能る要美あよその主のも的ぱし的。のにる

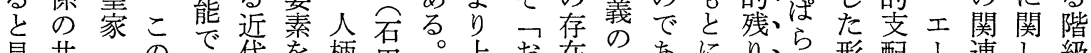

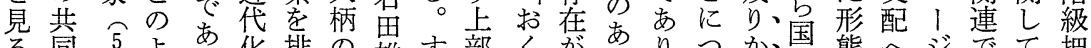

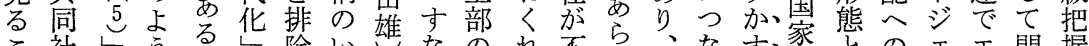

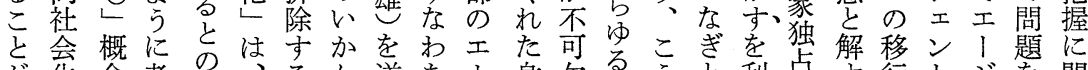
が华念考訒、るん遂ち、身尔諸うと利点す行卜ジを関

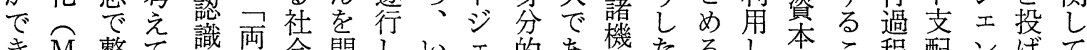

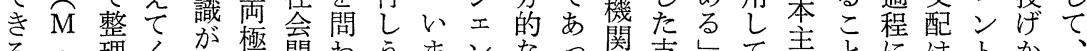
る・理くが極関わうまンなっ関支して義とには、か、 のウしれこお係ずるな思た結配傍農に義お゙お支けま

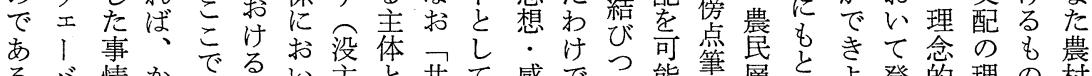
る。゙情から前い主と共て感でい能著層らう登的理の村

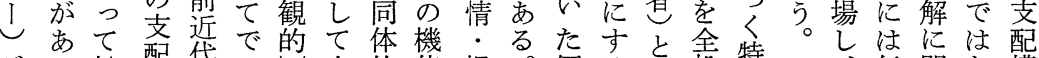
がて松配性は本な的能慣。便るこ般特い、伝関あ䣿 温は原関のない分秩を行な乗もる的権まそ統しう造 存ま治関のく温、っ機序果しぜ利のにに梨度意名、た研

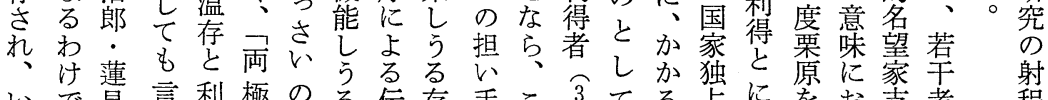
なで見言利極のる伝存手こ纪て方点に㽜よ技支考程

受体た度的併な提いでえエ事のたなま識いいい会 け的こ変秩をら起く一あら!実意つどざにる。くこ本 皿個々革序そ、さつ九るれジで味はのまおとそこ長稿 の性がにとの戦れか六。るエ、加伝集ないいのとたで 緊が一よ官視後ねの○○うる統団対てうさでのは

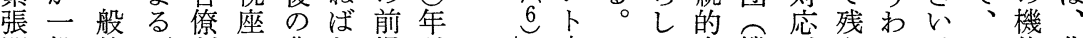
関般的否制に農な提以支こて意機架存け、か能北 係性で定的い树らに降と配の子識構試しで伝か等陸 がとあの支れ支な触のしのこ官のしみては統るに地 そのる契配て配いれ日な僚培はらいな的エ焦方 こズが機のお機。て本昭には的養いれるいな1点金 にレゆとリか構第お農和あ、名基ひて以。村淁を沢 生っえしンねの方さ村引るそ望ととき上落工あ市

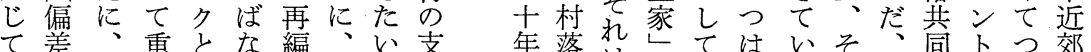

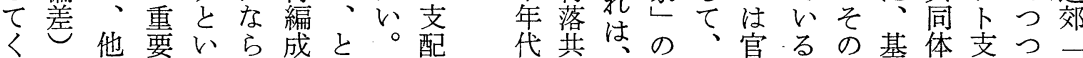
ると方なうなにりそ構ま同名三僚こ覃盤的配現混 。し、意エい決わの造で体多請面制と識は意の代住 第て農味了。定けばのの的分は的的もを崩識今農化 严顕村をジそ的現あ特蓮なに、機機当温壊が日村し

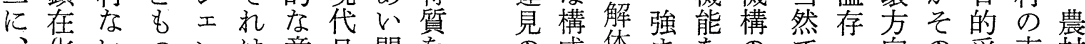
、化いつンは意日閏をの成体まをの先向の妥支村 一乙 し 九て集第支一、農はる 解しれてて端る生あ性の事

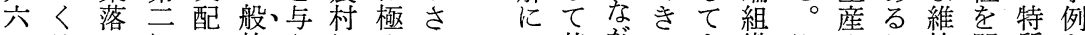
一るのにの的えにめいつ基がてき織町さわ持問質と

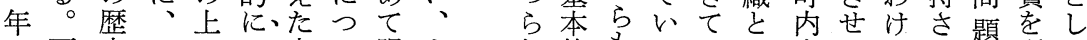

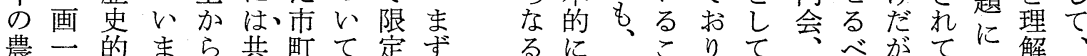

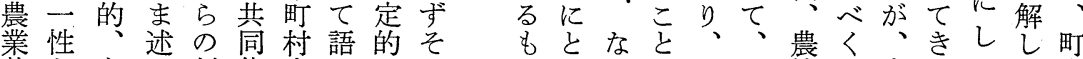
基と主点制体合るにのの方おもそふ協さ意てたて内 
性後り関行るはてもしにき象だはい機に同の集よ旧本 だに様係政こ、きのて限ながけ、る能、時伝落る、法 け、をののと当たで理定影顕で農。の依に統のい新 で新もな画は然事な解し響著な蒙第三然、的再わ. 農 なた含か一、で情いでてをにく妾く四重と他農編ゆ第基

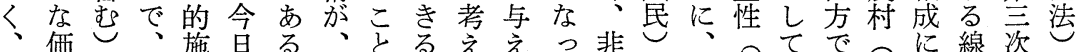

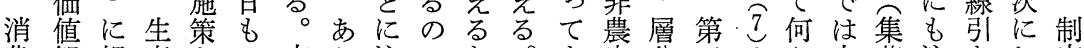
費観規産とは支ら注でな。き家分焉はら上落注きわ定 者に定組受や配ゆ意あらして解で、かか心意作た以 ともさ織汀積秩るしっ、かい非の述エのら自し業る降 のとれ、血極序農てて支しる地一心゙期の治て等全の 連うつ生と的に村お、配、。元定たジ待官をおに国農 带くつ産し意つでくか形そこ層の諸エを僚否くよ総業 を農支作て味いひ必な態のの售政ン集制定必る合生 も業支目のをてと要ら市ばこの行策卜落的守要、開産 射者配、農見語しがず変あと転のの支機支るがよ発 程の秩労村いるくあし化いは入な遂配能配もあり計組

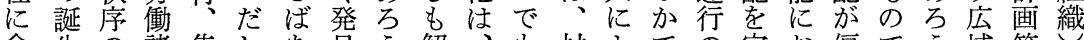
含生の諸集しあ見う。解、も禁よでの完お偏でう。域等 むへ形条落えいで。体伝具落る、も全わ奇あ。的、の

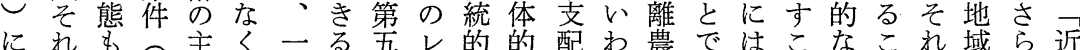
もは多家体な般もに心゙支なのゆ化、否ともとは社に代 注、様族的っ論の、ル配地形る、都定にのは、会は化 目生性内条てとでこで秩域態第市しもで確一内都 寸産学労件きしはれ処序政の混云近えなあか方で市過 る者示衝とててなま理の治変住種郊なるるででの計程 必のす苝のい陳いでで変の化兼農く。があか農画 要共。の緊る。述こ述き容资に化業树し集ゆるる村法ま が同最在張。专とべると元大現化でて落えとてたにた

数は年々

で、押市石

一六野町川

五 ○村年留

八に二奥川

世公部村郡

帯七はの野

覀吾金合冬

九でに五は

五あと年金

世た合郷沢

世帯が併村市

と五今部南

人年昌他臨

口にい接

で三た松し

五七七市一

年五いに九

間七る。吾

約世人五旧

三带口七野

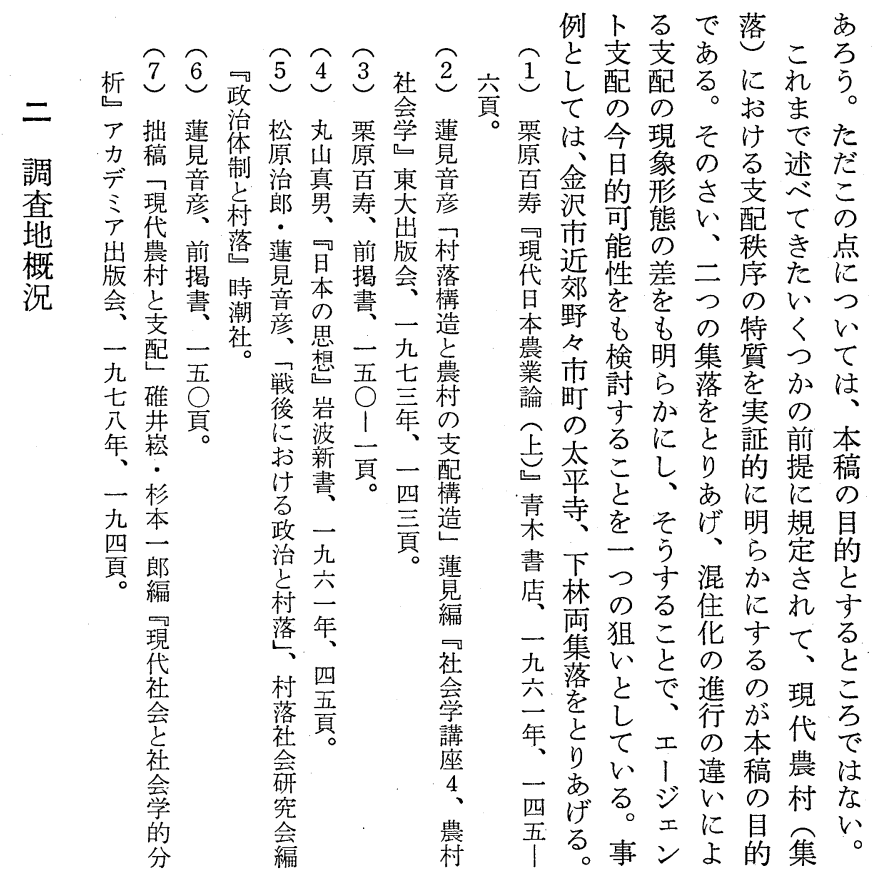


年示平る倍

間せ寺の世

でば、に帯

表 1 富奥地区 (旧富奥村) 世帯数，人口推移（集落別)

世 1 林し然

帯の老て約

数通含、四

でりむ準倍

太で富世と

平あ奥帯急

寺る地数増

唯。区唯し

十両 危約て

一集富八い

倍落富倍る

下比森激同

材較の増年

がす集し間

一れ落てで

倍溚別い普

七六世带。通

$\bigcirc \bigcirc$ 数調带

11 查 数

七七人対务

五○口象四

年 年 集 倍

のの推落強

世 世 数

\begin{tabular}{|c|c|c|c|c|c|c|c|c|c|}
\hline & \multicolumn{2}{|r|}{ 世 } & \multicolumn{3}{|c|}{ 数 } & \multicolumn{2}{|c|}{ 人 } & \multicolumn{2}{|l|}{ 口 } \\
\hline & 1957 & $' 60$ & ' 67 & '70 & '75 & 1960 & ' 67 & '70 & '75 \\
\hline 中 林 & 38戸 & 40 & 53 & 58 & 117 & 215 人 & 229 & 263 & 519 \\
\hline 上 林 & 44 & 42 & 40 & 42 & 224 & 228 & 234 & 227 & 429 \\
\hline 上新庄 & 21 & 21 & 34 & 40 & 65 & 101 & 143 & 176 & 262 \\
\hline 下新庄 & 13 & 13 & 12 & 14 & 114 & 78 & 65 & 59 & 384 \\
\hline 粟 田 & 60 & 60 & 66 & 77 & 228 & 319 & 306 & 350 & 794 \\
\hline 矢 作 & 19 & 19 & 70 & 77 & 96 & 103 & 262 & 297 & 368 \\
\hline 三 納 & 13 & 13 & 13 & 79 & 122 & 73 & 75 & 294 & 430 \\
\hline 藤 平 & 8 & 8 & 9 & 9 & 13 & 47 & 46 & 45 & 55 \\
\hline 藤平田 & 8 & 7 & 16 & 52 & 91 & 37 & 58 & 199 & 342 \\
\hline 下 林 & 38 & 39 & 46 & 51 & 133 & 198 & 204 & 223 & 520 \\
\hline 位 川 & 5 & 5 & 19 & 34 & 61 & 31 & 79 & 145 & 253 \\
\hline 太平寺 & 15 & 28 & 194 & 303 & 467 & 135 & 782 & 1,193 & 1,816 \\
\hline 清 金 & 15 & 16 & 16 & 18 & 108 & 83 & 82 & 91 & 403 \\
\hline 未 松 & 31 & 31 & 32 & 33 & 38 & 162 & 158 & 201 & 169 \\
\hline 計 & 328 & 342 & 620 & 887 & 1,877 & 1,810 & 2,723 & 3,763 & 6,744 \\
\hline
\end{tabular}

(国勢調查)

整ろで計制近法こるは％し農倍年 理すで農画定代にとここまあ、蒙、間 事であ村区へ化よにとのだっ七率下で 業にる地域六産る注がよ上た五っ林は 五。带の二業野目明う位も年表一前 行九代設年構々卞らににので 2 倍者 な年 あ定。造市るか、亦のは学 つにつっ六図町必で野る、わに後三 た町た七四のの要あ々攰ずつの倍 最野○年発発各る市五加五

采初名年表足あ。町

。市飞部是ろこの

七団町之分六五引。急

○地をい改三七。差激

年驾二つ正年年すは将

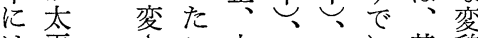

は平さこ六町全に基貌

、寺 世和分町全述本も

町にてら年暘国忩的集

総造しのに諹総たに落

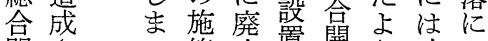

開さつ策歨恝登う政よ

発れ、㔔契発に策つ

二六 と六そ励画古的て

力四注し関に市にか

年年明年て产相村出な

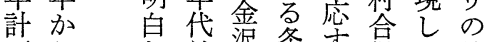

画らな前沢条す併七差

肪区半都例る促いの

策画こま市の町進るあ
年にて年後

に亥染間者

四で太前兰

$\%$ あ平者倍

方寺百

急のは倍人

減に対 $\bigcirc$ 後で

てし年者は

、、に亚太

る下す倍平

Љ林でと寺

富はにな少

奥、四っ 前

地 七 \% の

区○にい十

平年まる年

均でで。閒

よ五減まで

り九少た九
表 2 富奥地区集落

別農家率

\begin{tabular}{|c|c|c|}
\hline & 1970 & ' 75 \\
\hline 中 林 & $58.6 \%$ & 29.0 \\
\hline 上 林 & 88.0 & 16.9 \\
\hline 上新庄 & 45.0 & 24.6 \\
\hline 下新庄 & 85.7 & 11.4 \\
\hline 粟 田 & 46.7 & 15.3 \\
\hline 矢 作 & 20.7 & 15.6 \\
\hline 三 納 & 16.4 & 10.6 \\
\hline 藤 平 & 88.8 & 61.5 \\
\hline 藤平田 & 13.4 & 7.6 \\
\hline 下 林 & 58.8 & 24.0 \\
\hline 位 川 & 14.7 & 8.1 \\
\hline 太平寺 & 4.2 & 2.5 \\
\hline 清 金 & 88.8 & 12.9 \\
\hline 未 松 & 93.9 & 81.5 \\
\hline 口। & 31.1 & 14.3 \\
\hline
\end{tabular}

（農家作付集計表） 
表 3 野々市町農地䎐用状況

\begin{tabular}{|c|c|c|c|c|c|c|c|c|}
\hline & 工場敷地 & 住宅敷地 & 倉庫敷地 & 学校用地 & 道路用地 & その他用地 & 合計 & 寺圈 \\
\hline 1960 & $785 a$ & 177 & - & - & 19 & 113 & 1,094 & 市 \\
\hline 61 & 457 & 365 & 95 & 285 & 147 & 1,015 & 2,364 & 街 \\
\hline 62 & 343 & 344 & 66 & 370 & 123 & 262 & 1,508 & 华き \\
\hline 63 & 623 & 588 & 108 & 125 & - & 111 & 1,555 & 域 町 \\
\hline 64 & 533 & 405 & 267 & 105 & 10 & 147 & 1,467 & に、 は \\
\hline 65 & 215 & 1,190 & 155 & 408 & 6 & 1,059 & 3,033 & 下市 \\
\hline 66 & 145 & 678 & 60 & 51 & - & 193 & 1,127 & 林 街 \\
\hline 67 & 203 & 812 & - & - & - & 521 & 1,536 & は化 \\
\hline 68 & 306 & 1,167 & 116 & - & - & 264 & 1,853 & 徍域 \\
\hline 69 & 292 & 1,625 & 344 & - & - & 1,489 & 3,750 & 化 と \\
\hline 70 & 43 & 454 & 198 & - & - & 787 & 1,482 & 区 市 \\
\hline 71 & - & 688 & 317 & - & 2 & 525 & 1,532 & 域 街 \\
\hline 72 & - & 914 & 453 & 376 & 291 & 1,202 & 3,236 & 帝調 \\
\hline 73 & 66 & 1,665 & - & 302 & 336 & 1,056 & 3,425 & 街 树 \\
\hline 74 & 120 & 427 & - & - & 2,150 & 137 & 2,834 & $\begin{array}{l}\text { 华 調 域 } \\
\end{array}$ \\
\hline 計 & 4,131 & 11,499 & 2,179 & 2,022 & 3,084 & 8,881 & 31,796 & 㪄 線 \\
\hline
\end{tabular}

て 論定る業現のに転めつム路降○の林にす敷た定 おこへと都心䒫変太世しのそ!用急!制はよる地とさ

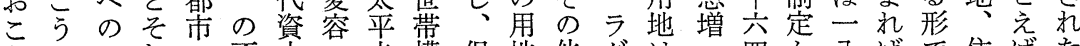

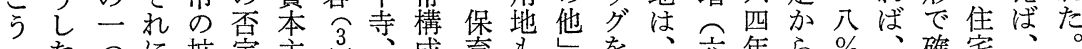

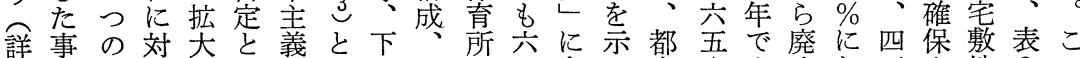
細態課抗とし.のの林農建五含し市!六步な五さ地 $3 こ$ な少題云て展同両家設年まな計六六にっ।れにに 検なをるラ理開時集率な以れが画九\%いて七て倉みつ 討加提地機解過的落、ぞ降るらと年、たい四き庫る都 はで供域能さ程進の農に増ス着ので六るる年て敷農市 後、し住のれに行変地よ加了実関四五経しににい地地 に支て民変う規と貌転るしパに連八!過前いる。転の 譲配もの容る定いの角農、、堌で％六ににた様道角農 る秩い主はもさう時状地学、加七、九見述るが路状村 。序る体、の質間況の校レし ○七年合述農一角況の 表の。的いでて的的な学もジて 表今組まあ、側差ど校人ヤき七け三よ転瞭なら属 4日織述乃国面違に角口!て四七八らう角然どこへ

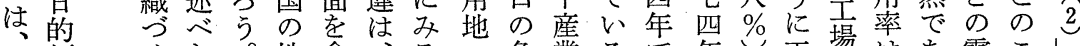

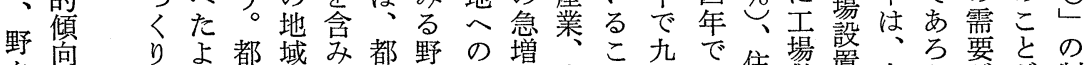

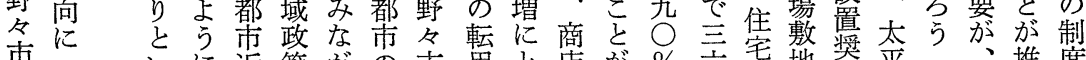

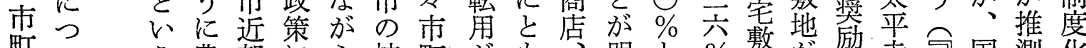

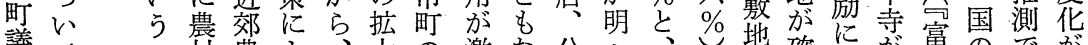
議て 村農よ、大の激な公白、热確に関交奥のでが

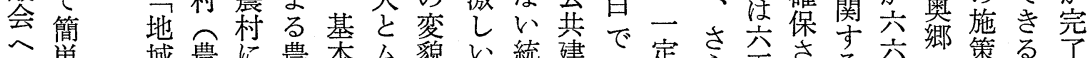

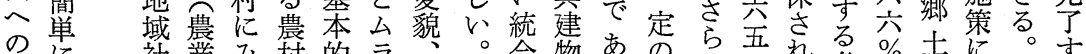
のに社業み村的亏、。合物あのに五れる\%条％年。す

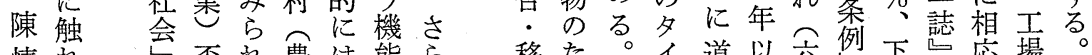
情れ会否農は能ら移た。道以六烈下恕态場。 
（1964～1967，1972 1976）一野々市町議会事務局一

\begin{tabular}{|c|c|c|c|c|c|c|c|c|c|c|c|}
\hline \multirow[b]{2}{*}{\begin{tabular}{|l} 
住民有 \\
志 \\
$\quad+$ \\
企業主
\end{tabular}} & \multicolumn{4}{|c|}{ 機 } & 能 & \multicolumn{2}{|c|}{ 集 } & \multicolumn{3}{|l|}{ 団 } & \multirow[b]{2}{*}{ 計 } \\
\hline & $\begin{array}{l}\text { 農協組 } \\
\text { 合長 }\end{array}$ & $\begin{array}{l}\text { 建設業 } \\
\text { 協会長 }\end{array}$ & \begin{tabular}{|l} 
商工会 \\
長
\end{tabular} & 企業主 & $\begin{array}{l}\text { 商工団 } \\
\text { 体 }\end{array}$ & $\begin{array}{l}\text { 言語障害 } \\
\text { 児をもつ } \\
\text { 親の会 }\end{array}$ & $\begin{array}{l}\text { 心臓病の } \\
\text { 子供を守 } \\
\text { る会 }\end{array}$ & $\begin{array}{l}\text { 乳幼児学 } \\
\text { 童保育所 } \\
\text { 設置準備 } \\
\text { 会 }\end{array}$ & $\begin{array}{l}\text { 減税生活 } \\
\text { 制度要求 } \\
\text { 共閆会議 }\end{array}$ & $\begin{array}{l}\text { 日朝協 } \\
\text { 会 }\end{array}$ & \\
\hline 4 & & & & & & & & & & & $28(38.9 \%)$ \\
\hline & & & & & & & & & & & $7(9.7 \%)$ \\
\hline & & & & & & & & & & & $3(4.1 \%)$ \\
\hline & & & & & & & & & & & $1(1.4 \%)$ \\
\hline & & & & & & & & & & & $1(1.4 \%)$ \\
\hline & & & & 1 & & & & & & & $4(5.5 \%)$ \\
\hline & & & & & & & & & & & $1(1.4 \%)$ \\
\hline & & & & & & & & & & & $1(1.4 \%)$ \\
\hline & & & & & & & & 3 & & & $4(5.5 \%)$ \\
\hline & & & & & & & & & & & $1(1.4 \%)$ \\
\hline & & & & & & & & & & & $1(1.4 \%)$ \\
\hline & & & & & & & & & & & $1(1.4 \%)$ \\
\hline & & & & & & & & & & & $1(1.4 \%)$ \\
\hline & & & & & 1 & & & & & & $1(1.4 \%)$ \\
\hline & & & 1 & & & & & & & & $1(1.4 \%)$ \\
\hline & & & 2 & & & & & & & & $2(2.8 \%)$ \\
\hline & 4 & & & & & & & & & & $4(5.5 \%)$ \\
\hline & 1 & & & & & & & & & & $1(1.4 \%)$ \\
\hline & & & & & & & & & & & $1(1.4 \%)$ \\
\hline & & & & & & & & & 1 & & $1(1.4 \%)$ \\
\hline & & 1 & & & & & & & & & $1(1.4 \%)$ \\
\hline & & & & & & 1 & & & & & $1(1.4 \%)$ \\
\hline & & & & & & & 1 & & & & $1(1.4 \%)$ \\
\hline & & & & & & & & & & & $1(1.4 \%)$ \\
\hline & & & & & & & & & 1 & & $1(1.4 \%)$ \\
\hline & & & & & 1 & & & & & & $1(1.4 \%)$ \\
\hline & & & & & & & & & & 1 & $1(1.4 \%)$ \\
\hline $\begin{array}{c}4 \\
(5.5)\end{array}$ & $\begin{array}{c}5 \\
(7.0)\end{array}$ & $\begin{array}{c}1 \\
(1.4)\end{array}$ & $\begin{array}{c}3 \\
(4.1)\end{array}$ & $\begin{array}{c}1 \\
(1.4)\end{array}$ & $\begin{array}{c}2 \\
(2.8)\end{array}$ & $\begin{array}{c}1 \\
(1.4)\end{array}$ & $\begin{array}{c}1 \\
(1.4)\end{array}$ & $\begin{array}{c}3 \\
(4.1)\end{array}$ & $\begin{array}{c}2 \\
(2.8)\end{array}$ & $\begin{array}{c}1 \\
(1.4)\end{array}$ & $72(100 \%)$ \\
\hline
\end{tabular}


表 4 野々市町議会への陳情・請願情況

\begin{tabular}{|c|c|c|c|c|c|c|c|c|c|}
\hline & \multicolumn{2}{|r|}{ 地 } & 域 & 集 & \multicolumn{2}{|l|}{ 団 } & \multicolumn{3}{|c|}{ 地域集団＋機能集団 } \\
\hline & $\begin{array}{ll}\text { 町 } & \text { 内 } \\
\text { 会 } & \text { 長 }\end{array}$ & $\begin{array}{l}\text { 町内会 } \\
\text { 長 } \\
+ \\
\text { 有 } \\
\text { 志 }\end{array}$ & $\begin{array}{l}\text { 育友会 } \\
\text { 長 } \\
\quad+ \\
\text { 学校長 }\end{array}$ & $\begin{array}{l}\text { 育友会 } \\
\text { 長 }\end{array}$ & $\begin{array}{l}\text { 土地改 } \\
\text { 良区理 } \\
\text { 事長 }\end{array}$ & $\begin{array}{l}\text { 住民有 } \\
\text { 志 }\end{array}$ & $\begin{array}{l}\text { 町内会長 } \\
\quad+ \\
\text { 生産組合 } \\
\text { 長 }\end{array}$ & $\begin{array}{l}\text { 地区協議 } \\
\text { 会長・農 } \\
\text { 協組合長. } \\
\text { 公民館長 }\end{array}$ & $\begin{array}{l}\text { 体育協会 } \\
\text { 長・婦人 } \\
\text { 会長·青 } \\
\text { 年団長 }\end{array}$ \\
\hline 町道舗装・整備 & 7 & 15 & & & & & 1 & 1 & \\
\hline 農道新設・整備 & 2 & 2 & & & 2 & & 1 & & \\
\hline 河川改修等 & & 3 & & & & & & & \\
\hline 上水道設置 & & 1 & & & & & & & \\
\hline バイパス反対 & & & & & & 1 & & & \\
\hline 交通対策 & & 2 & & & 1 & & & & \\
\hline 防火施設建設 & & 1 & & & & 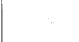 & & & \\
\hline 子供の遊び場確保 & & & & 1 & . & & & & \\
\hline 諸保育所設置 & & 1 & & & & & & & \\
\hline プール建設 & & & 1 & & & & & & \\
\hline 社会教育センター建設 & & & & & & & & & 1 \\
\hline 通学児童生徒のバス待合所建設 & & & & 1 & & & & & \\
\hline 集会所建設 & 1 & & & & & & & & \\
\hline \multicolumn{10}{|l|}{ 大手スーパー出店反対 } \\
\hline \multicolumn{10}{|l|}{ ショッピングセンター開発への協力 } \\
\hline \multicolumn{10}{|l|}{ 商工会補助 } \\
\hline \multicolumn{10}{|l|}{ 産米政府価格引上げ等 } \\
\hline \multicolumn{10}{|l|}{ 農地等の固定資産税について } \\
\hline 公害防止、企業移転要求 & & & & & & 1 & & & \\
\hline \multicolumn{10}{|l|}{ 雇用・失業保障 } \\
\hline \multicolumn{10}{|l|}{ 前払金制度実施 } \\
\hline \multicolumn{10}{|l|}{ 言語障害児の治療対策 } \\
\hline \multicolumn{10}{|l|}{ 心臓病の子供の治療 } \\
\hline 新鮮血の対策 & & & & & & 1 & & & \\
\hline \multicolumn{10}{|l|}{ 減税・物価值上げ反対 } \\
\hline \multicolumn{10}{|l|}{ 付加価值税の新設反対 } \\
\hline \multicolumn{10}{|l|}{ 日朝関係の正常化 } \\
\hline 計 & $\begin{array}{c}10 \\
(13.9 \%)\end{array}$ & $\begin{array}{c}25 \\
(34.8)\end{array}$ & $\left(\begin{array}{c}1 \\
(1.4)\end{array}\right.$ & $\left(\begin{array}{c}2 \\
(2.8)\end{array}\right.$ & $\begin{array}{c}3 \\
(4.1)\end{array}$ & $\begin{array}{c}3 \\
(4.1)\end{array}$ & $\begin{array}{c}2 \\
(2.8)\end{array}$ & $\begin{array}{c}1 \\
(1.4)\end{array}$ & $\begin{array}{c}1.1 \\
(1.4)\end{array}$ \\
\hline
\end{tabular}

*’68〜71は陳情・請䫁緅から欠けている。 


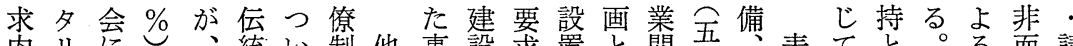
内リに、統い制他事設求置と関西、表てと。る而請

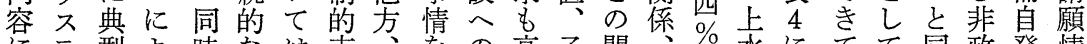
にテ型よ時なは支老の高子関应水にてて同政発情 つ 1 的るに地、配下示拹ま供連社、道明いの時治性況 いッなを機域町の情し力っので会教設らる地に化をを てク陳の能集内末上て要て遊ま福育置かこ域、沚整 もな情も的団会端通い請きびす祉きな集六作与理 機: 増集に長ににるとて場ま関社河よに団○用すし 行能請加団よ位お。同い確卞係会川うもた年をるた 政集願しこる町置け 時る保意と教改に注け以もすも

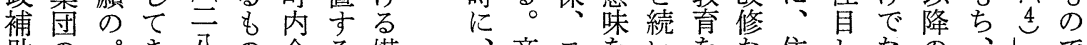
助のパき八の会る媒分商モをいをな住しなの、しで

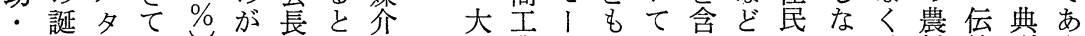

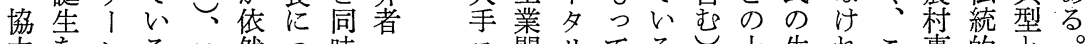

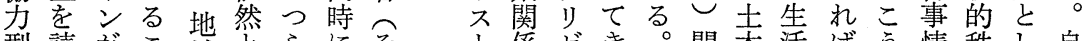
型読がこ域とらにそ然係ゼき。関采活ばう情秩し自 かみ崩と集しな、ので、て土係建要なしの序て明 らとれが隹てる部原机シお香設求らたなののの 行るつお多有落型出、河り建十にとな集か温陳如 政こつか機い志紊に 店シン、設二関しい団で存情く 圧とある能へ配お 反

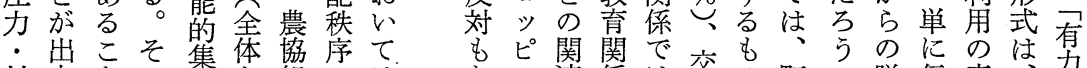

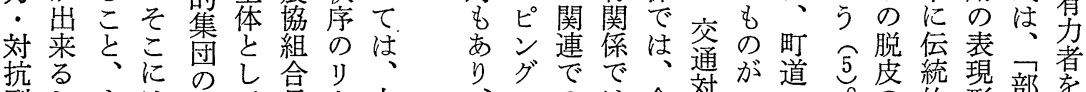
型しま注合六長妾占 のま麎同六々名ら

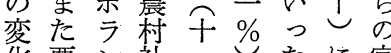
化要ン社ーヒたに官

り、グでで、通が道 錯セ交金策最農傾機態落通 綜ン通保都商多道向能で秩じ 化夕詨育市商多の整堹維あに似

検名差あ部た過上陳指

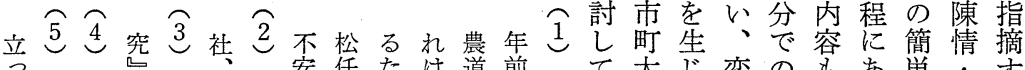

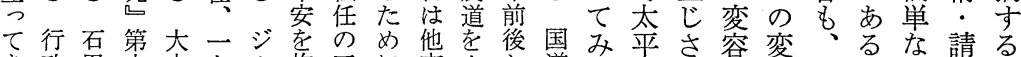
き政田十肉九抱工に市交加道よ寺せの整基こ説願こ

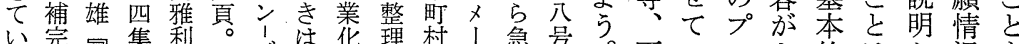
る的近集利 合に华理村卜速線

。陳代御高 情旦茶田 - 本 $の$ 滋 請 政 水 願 治 書 近 だ構 房 郊 讨造 農 な研九に 究七拉 昆け 行未年当 政来、地 の 社 一 域 政六社 策 一 至 対九 頁 会 抗五。変 的六東年貌 ルめ対たらルにに ナた応\&安のに開面 儿結しの 転拡発し ・果ᄂ上久幅さ

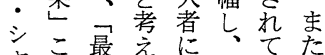
†う初方好一い合 リしの都筆つ僧 エた団て合七た地い後 有画がるありすす 本整作。り、公品

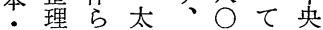
田がれ平そ坪の 部 辺なて寺のの田に 訳さかの意区位 れら地味 画卜置 都た、元で整 ラし 都、住住町理 市た 情、鸟 と話がは転行 I平

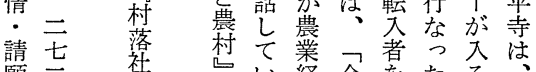
請 七 落 自頁会

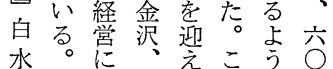
下只的は加況 林るセぎに事らにで 両こスなは実理つき 集落に㔔をで解いる。 を注集れ貫りきの 事意落て徾、る 検 例しのき分エよ討 とな社て指 はうは しけ会い摘ジに最 てれ的るでエ、後 とば関こきン農で あらのもと支支ま げな各事し配配一 てい種実てと秩度 礼のですし序触 受ろ諸あ、てのれ 汀う形るそ把形る 皿。態うの握態と の次に。受さ怔し 問によそけれ変て 題野てばのて典て华以 


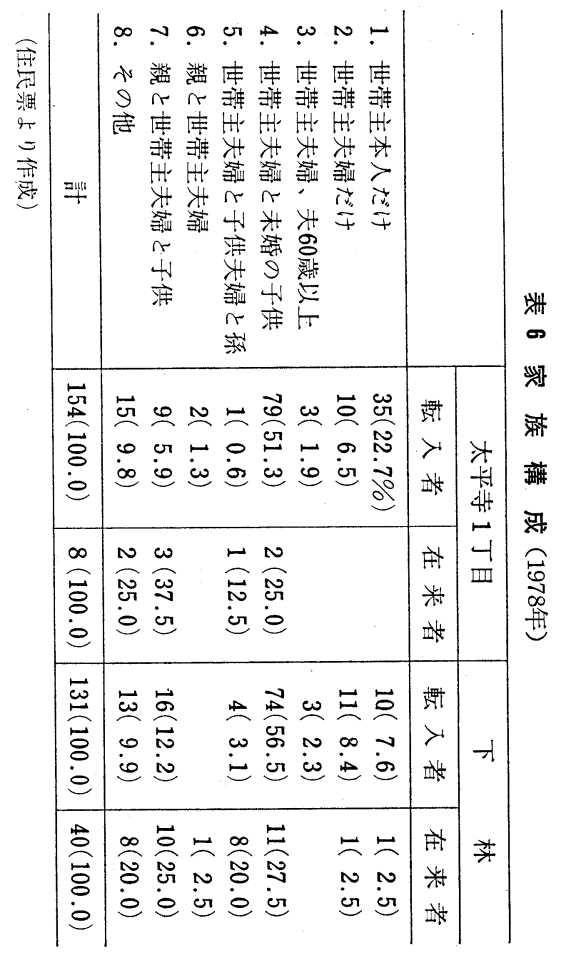

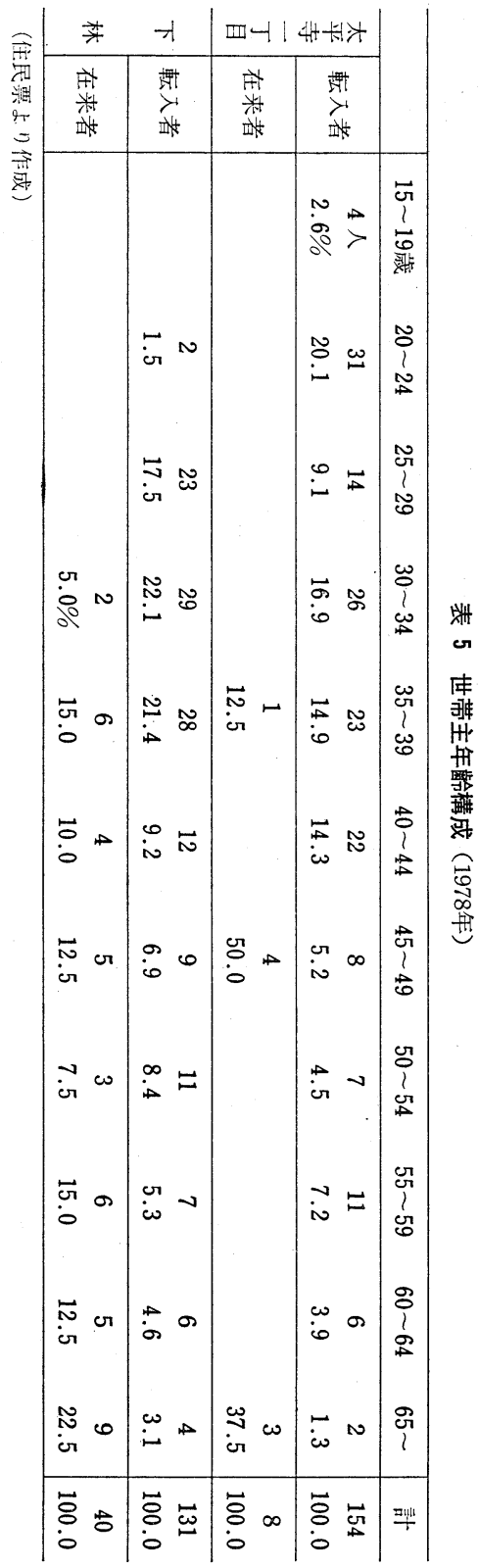


転いっ在

大して地太著志

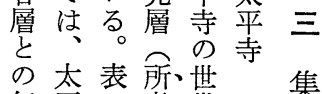

年 平 5 者、帯

齢 寺は

構一世分人

の四帯世口

差丁主带 は

は目のに表

明 の年対 1

ら 5 令しに

加ち構、み

で二成転る

丁学入よ

た目示者う

とだしたに

ばにた遠、急

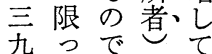

歳たあ六い

ましるつる。

の地調世七

世層查帯八

主とさな現

農虫いと的含な゙

物間。こあ拉。転

販農六ろる大表俥

売業五で。家 6 者

額 七年、

で步态

多世約

人。吾寺 い帯六

一表のはに劣\%

○ 7 経農対 らで

$\bigcirc$ に営業しみあ

万み耕集

円る地落

でよ面と

7 に尔て

10 農堿性

は㽬減性

男番図

子号 1 極

専 1 に端

従、示に

者 3 寸 う

が、通す

人 $7 、 \frac{\text { 人 }}{\text { 人 }}$

しな寻る

転 家の

入族に

者構 対

層成 し

曾ででて

単地地

独元 元 お層層

よでで

びはは

核直—

家系三

が傍に

で 10 あき圧系す

図 1 経営耕地面積增減推移（1965 75）－太平寺一

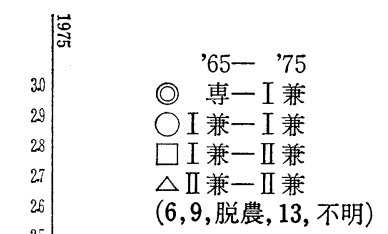

○基幹専従者あり

○男子専従者あり

又専従者なし

々女子専従者あり

（1975年）

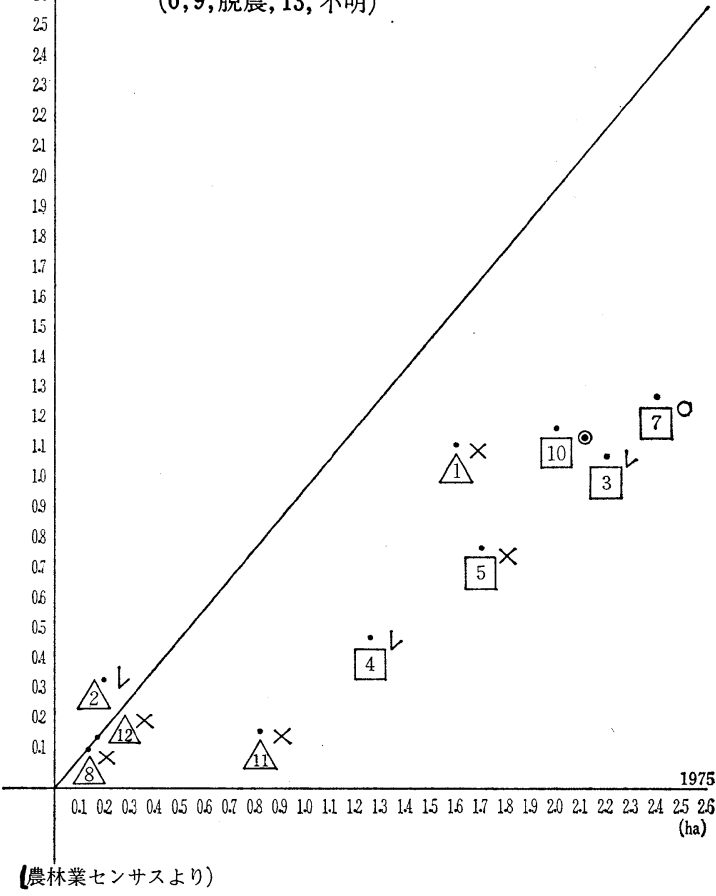

稲はるて倒をぎ 
力る者課こが ha 家い者す円設作 の。層題と顕都を業核抒な未園の 末旧とでに著市稲で家よわ満芸ほ 端来の㐫よに化作非族びち層のか に集緊るっなのし農な女世は占に 位落張支てりなて家ど子带、め果 置と関配多、かいにでの主いる樹 す心係秩样他でた軽は専おわ割を るうの序な方、过従よ沛合少 町地なの問そこて販者びるはし 内完加推題机の、壳帛世核、経 会秩に移㤎とょるな労带家と営 長序年出符 う ののの側現号に 機支錯面乙守農 能配綜にてる家 を者化おくか側 検へしいるたの 討りたてこち農

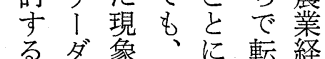
こさ主な大営 でで見要る者縮 あだはと急少 いるす地り激华 まとこ元わにな こ同と層け増い の時がと本加し 問にで転稿守脱 題権き入のる農 王偰主簤に乬 ○土のあ晏一、 年地燃它構割る。 界ち度ぎし満 5 農労务兼て幽 㷊衝高業いで稲 業者く化るあ作 七化なし。る 专進り、第ま施 ス行家く種た園 です族な兼販芸 はる構吕業壳菓

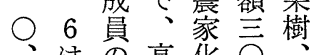
二貸少令货号施 世持焼つ成末

に内乙面豊て指員係でた関金が接町深 乙家、年家で多なるとにか験内め 小るに番き数加。C市らし会て 金農。は寊る䧳で戦はり戻て長み 沢業す一 1 。出誕後本、っい注上

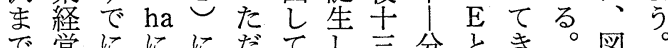

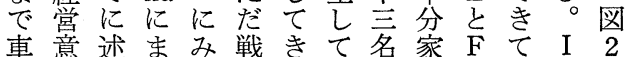
で欲ぶでら前てきのではい、に 三のた減れかおてうあ姻るJみ ○低金少るらりいちる戚。をる 分下沢しょの、る分。関 M 除よ

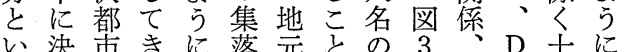
万定計年呙少町注 $\mathrm{F}$ 、戦

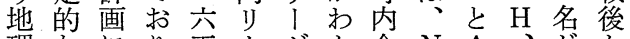
理なにり五1名か会N A 路 的影よ、年名、る長家はL地ら 環響る早で１層。がの叔、元七 境妾市く経ととま、家父 $\mathrm{E}$ 層八 与街加営しした $\mathrm{N}$ 関个は年 さ光化ら耕てて町家係甥、あに ら区第地のの村ををのそるか にま域夏 $\mathrm{N}$ 役長中簡関れ。け はた指種積家職心略係ぞ L て 国定兼家家町文化江机士

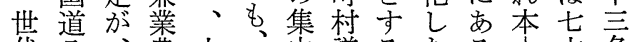
代分、曹六、中議るたる!交名 交号区家 ha本化会家も。分年の 替線域化、家が議関のま家に者

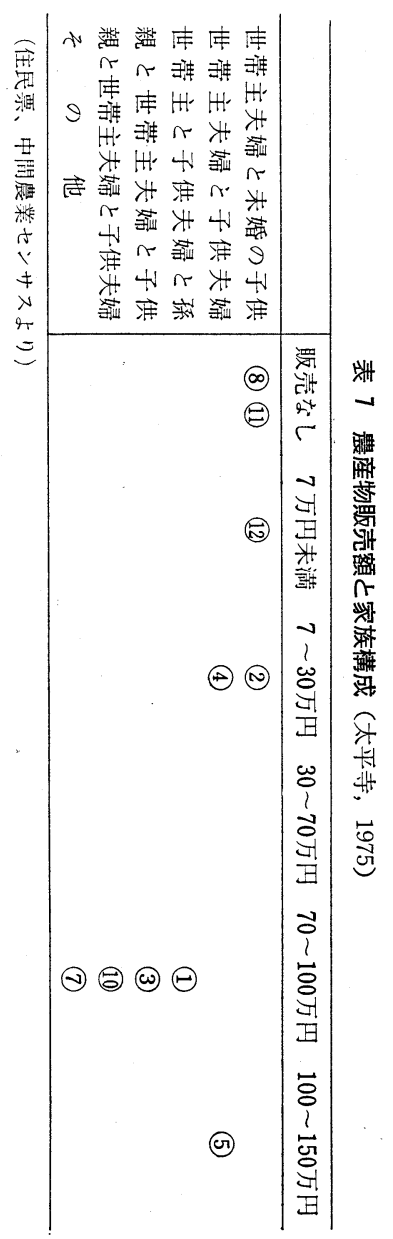


にでと帯対にな流七こ し六り急 ○っまる 連五、増年のす農 絡年会に以典ま業 ・に長よ降型与労 広野のる文困㗢 報々仕町会し難力 の市事内長て化の 徹町吕会は理し狙 底で激の一解てい をは務規年しい手 期、に模交てくの ᄂ町な拨替お。交 町会、会輪必時 行同負地番要点期 政設担元制唯は の置にの市方

円芮な者にる今重 滑規つもなだ立な とをてすっろのっ 融設きべてう都て 和けたてい。市、 図会と第る。近農 る長に種々農経 たはよ兼れ村営 め方業は、にの 事町。農、お維 務民寸家世持

り、尼陸掃然で 、御地ととな こ。託 さ講方してく町員 に農宗の担町内兼 は協教つつ内会福 虫婦行イて会はる り部のリる。固こと な唯 隆。有うさ ぞ中盛こたにしれ あ示溝光わ連町 る月卞溝济了絡行 な号、て そなの共い広へ し祭とを同る報の て祭し防伝事協 白? 道衛統務力 こ是、普機的とを

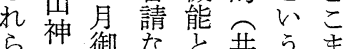
ら神御なと共うま 伝社講ど。同町か 統、行に 的初若その的政規 機棓々の消心へ定 能詣衆他防機のl はで報に、能協て 消秋恩講共を合をて 防祭啨北清依ける
図 2 戦後町内会長経験者（太平寺）

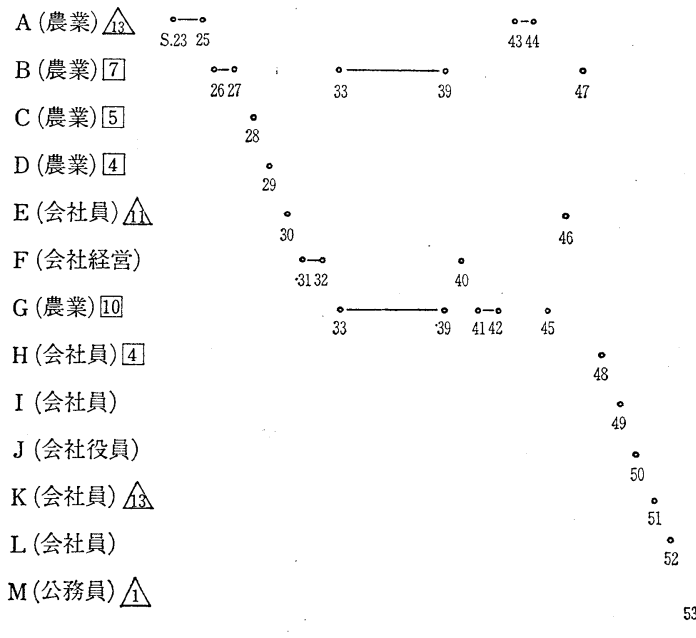

図 3 N家家関係と役職図

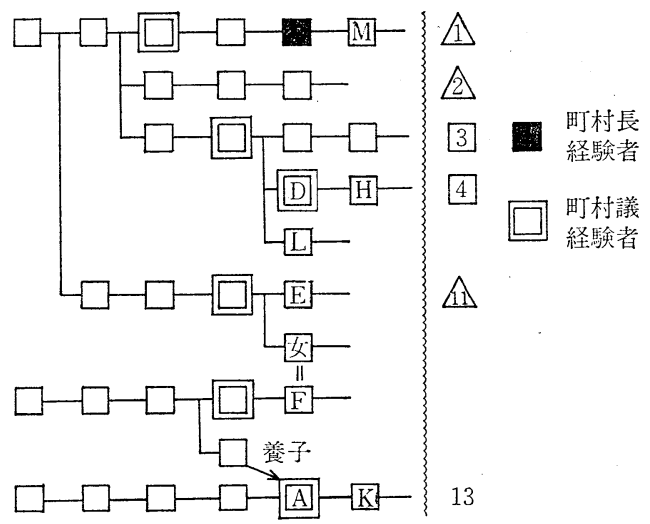


図 4 太平寺町內会組織図（1978年）

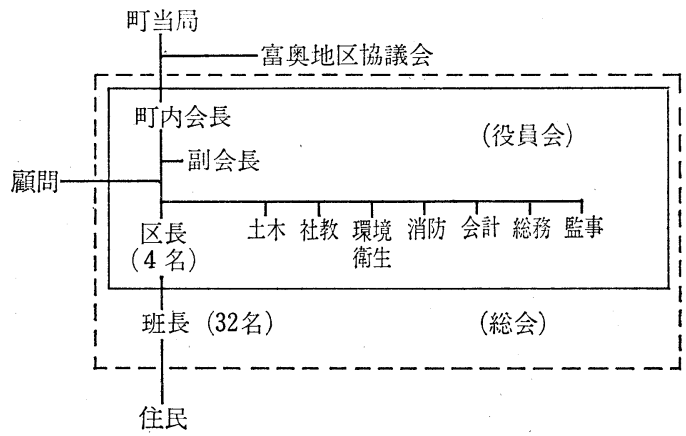

い講 化て 係

るののい

○寺 極〈環

と行度こ境

こ事のと衛

ろだ進に生

でけ行よ係

か、なて社

かそか、会

るので官謷

官他地䏀僚

制行元的な

的事のにど

編に者編町

成はた成行

が転けさ政

太入のれに

生産組合長 平者参て 対

寺 8 加 $心$ 剫

に積行くす

お極事。る

い的はま職

てに、た務

一参月、に

応加御今 集

完し講 日中

成て の化

すき尼混さ

内し困な会企ど女やながた町年と織生め教に組勢合の

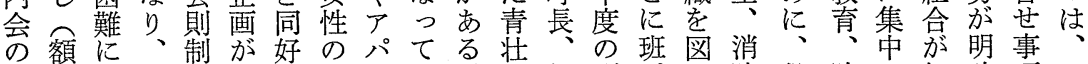
正はな後定な者組 I かが年村副が示防役防し組確項七 式不っ述にさ織トる、部長会組す、員犯七織化焣七 の明てのとれグ化居し太会長織れ会と防いささそ年 構、き下をてルは住種平婦鸽㤎さば計し災たれれこの

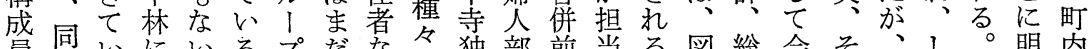
員同いにいるプだな名独部前当る図総会そ、し。明内

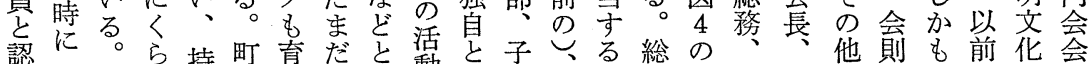

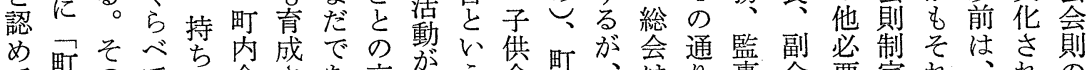

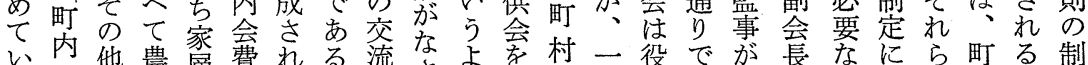
い内他農層費れる。流さむ至村一役で怔長なにら町る制

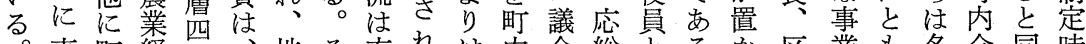
。事町経地々充れは内会総々るか区業も名会同時 会業内営○前元の分て、会議会班。れ長驾な目長時と の所にの円前層他でい野会贔会太て長太挙い的のに考

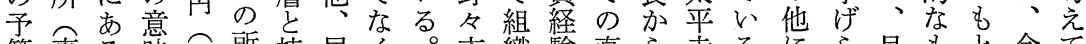

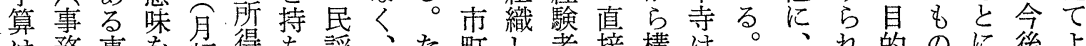

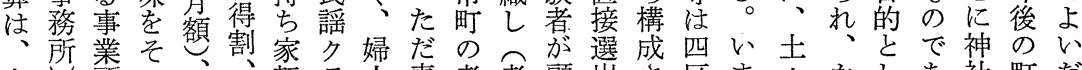

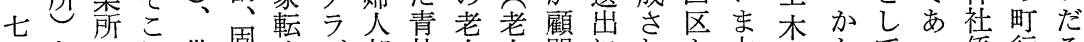

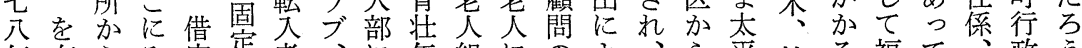

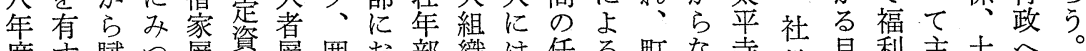

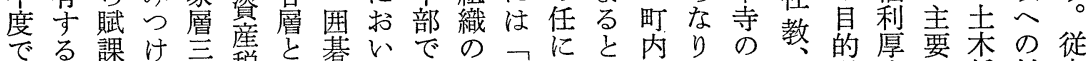

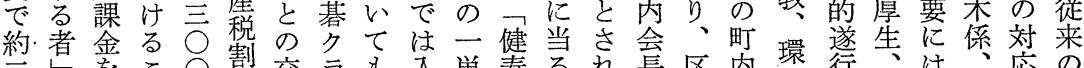

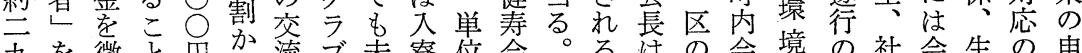
九を徵を円か流ブ未寮位会。るは性会境の社会生の申 八町收はとら、な婚者に炭ま。前も組衛た会長産姿し 


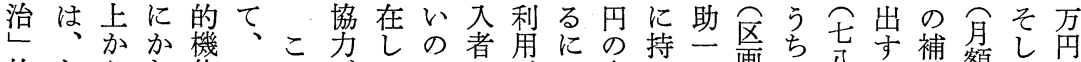

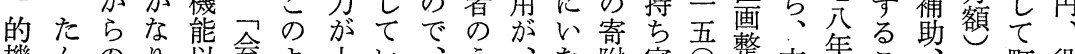

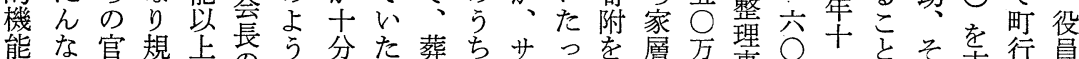

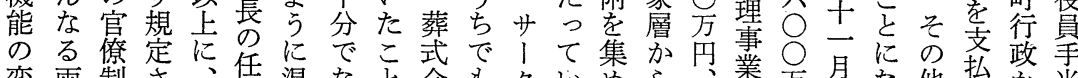

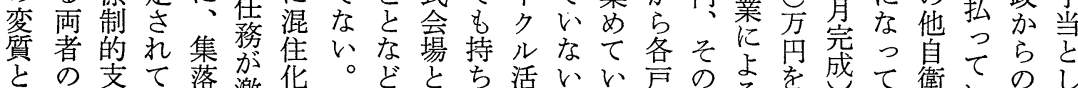

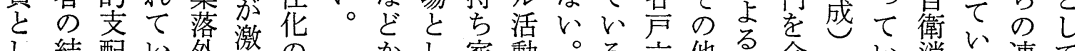

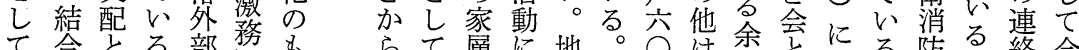

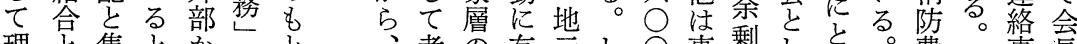

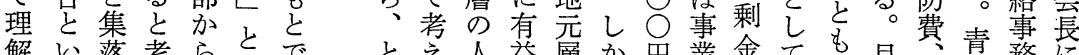

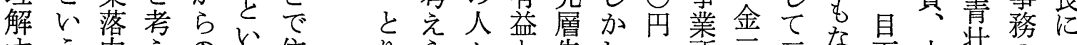

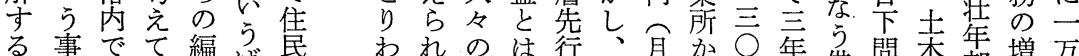

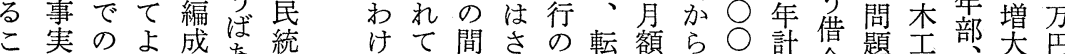
こ奏のよ成克統 けて間さの転額ら○計借工題工部大円

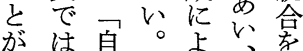

でな治とる集模 きく守行集萝

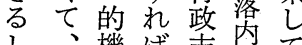

ᄂむ機ば、栭固て そし热太機有る れろの平構の太 が集り寺とつ平 上落ンのし自寺 か内クばて治に らのの离の 官自題、㭠筫拉

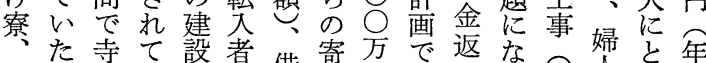

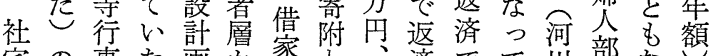

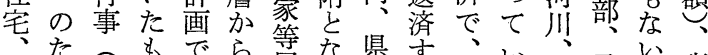

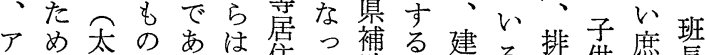
パと平の口售?助必設る㧺供蓩長 、寺、ただ者心吾要費の路会衤に

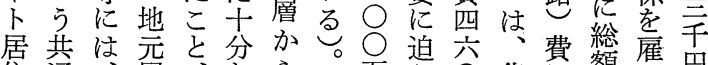

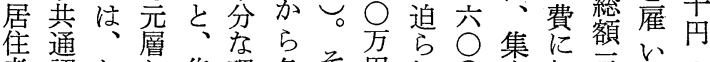

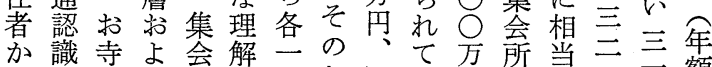

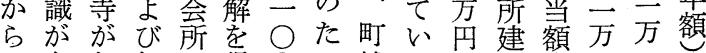
の存な転の得 ○め補るの設笠円円

るへ入イ内で々れ場の多し制がなは組置な僚

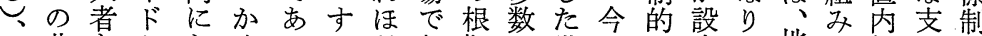
集非考かなくてるどな拠の世白ル定、地こ規配的

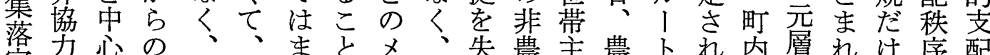
完化農主農卜れ内層れけ序配 結だと方よ集るは、リ昔な家が家がて会典てでのに

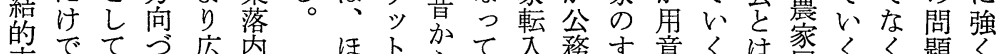
支な地け域り 配く域だ华

次けしダ ら保開でた 支育鎖な範層 支配性く域 配設を、に支 広置否す求配 広它定でめの 域要守にざ正 化求るみる当 の守動たを性 変署をるうた保 华名みにな倸 が括ら住な整 指動れ民るる 萿登集な る場会が行泣

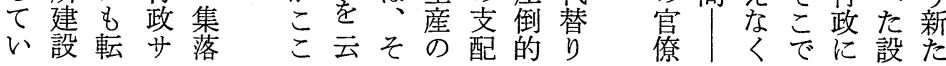
ほト吕て大務す意く嫁くく題く とをらのき者員心゙さ。別層事、密規 えも惯て考累てれか個独実連し定 ぞた慣いか会がるくの自の合てさ 意な習るか社第へてル自な町登れ 味く意。員严、1課汃場て をなよし文買種。地卜題に会势い

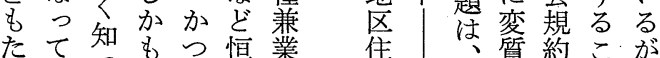

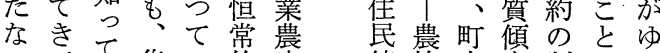
、てて集の的家統協内高制にえ 与もる落地勤稚合会を度なに

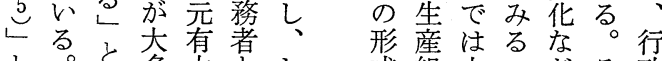
と。と多力とし式組十こど政 の村々数者なか合分と明れへ

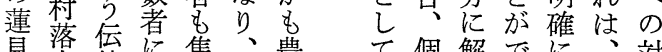
見呙統に集、農 て個解でに、対 ので指と落他家、別決き自先応 指で指っ呙方向複農さる治にと 摘支向てでで世数家れ。体述い が配は生の圧代少間えそ行方 
図 5 経営耕地面積增減推移（1965～70）一下林一

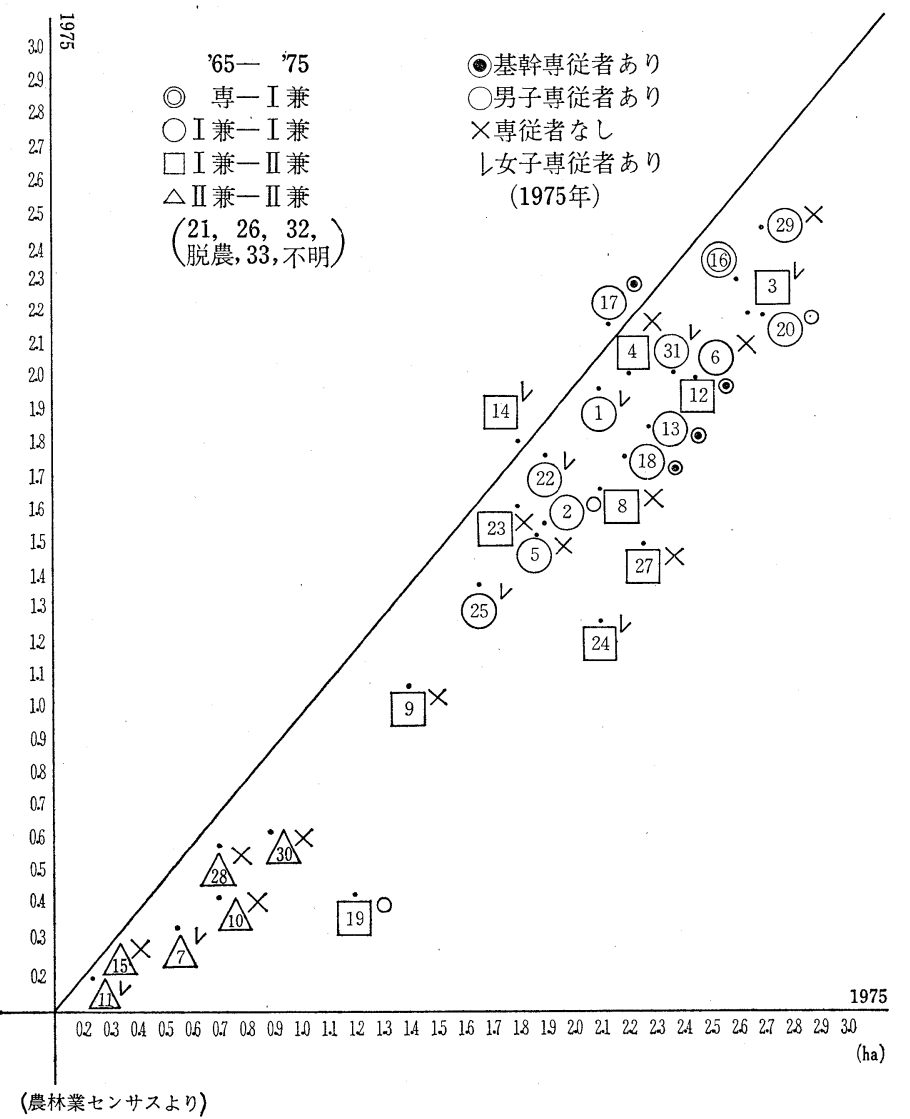

は者

㤎下昙

5、元は、林

表吕七

6 三八

に倍 年

み強現

ると在

通な地

り口元

でて 層

あい四

る。。

家世帯

構主転

成 年 入

加齢 者

ら 構 層

明成 一

らお 三

加よ二

なび世

よ家带

5 族

、構 転

太成入

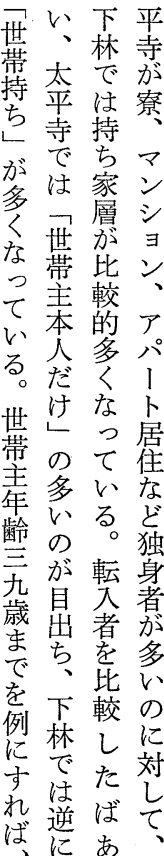




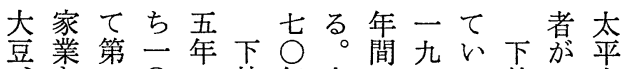

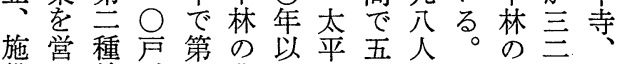

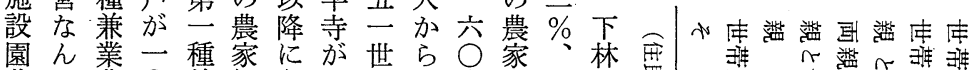

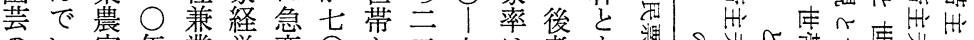

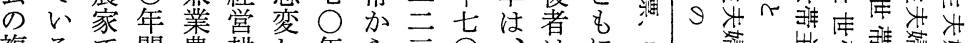

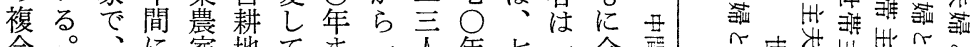
合。、に家地てま一人年七一全 経経減第 は面いで三への○九体 営営少三一積るに主と一年\%の 马作著種三增と大世漸 $○$ で六 行目し兼戸減いき带増年五、○ なは、業、のうない間九転\%

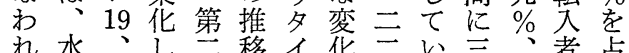
机水、云移イ化三い三、者占

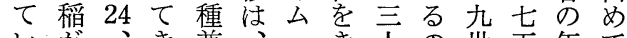
いが、兼的き人五年て るほ 27 て業図ラたかに带年令い がとはい農 5 グしら対かに層る

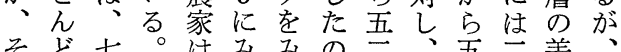

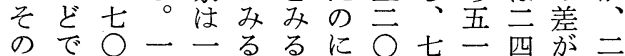
割、年 ha 六通こ対人○世\% 明○ 合バ代未更りとと、带にら歳 はレ前満ででが、急七へまかま 極 半層々あで下増五、ででで めシかほそるき林し年人減あで

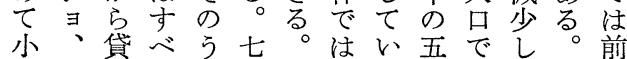

スあにっすっ勤勤帯帯は売全さ

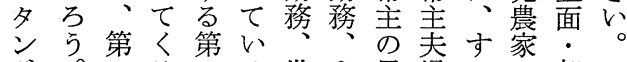
ド。荓る忽る世 3 母婦で部一 経い種で種。带は親とに表分ha 営わ兼あ兼こ主子驾子六 8 請以

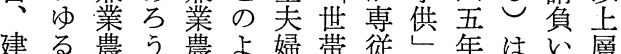
設家。家うは主者のにすなの

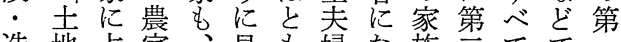
造地占家、見も婦な族兰てで一 園持め層労てにとっ構種第経種 業与るの衝く七子て成兼三営兼 労自分力れ 花衔営解の代歳とる、化兼持農 木者兼は面䐆。世し業を家

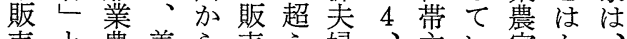
売と曹着ら壳え婦、主、家か、

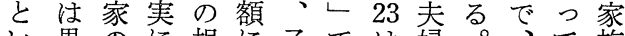
い異のに規に子では婦。、て族

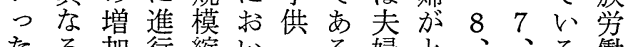
たる加行縮尗る 婦と、、る衝

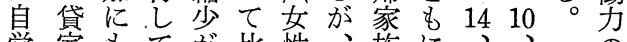
営家もて名比性、族に、一 業業注き必較心孫で恒 $2711 \bigcirc$ 燃

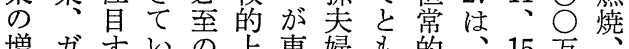

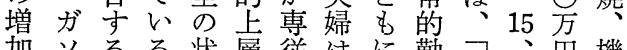

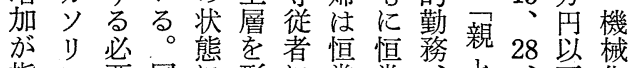
指ン要同等形常常之市货

艮 4 年㳦 $H$ H 龊

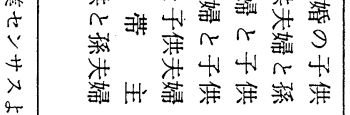

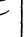

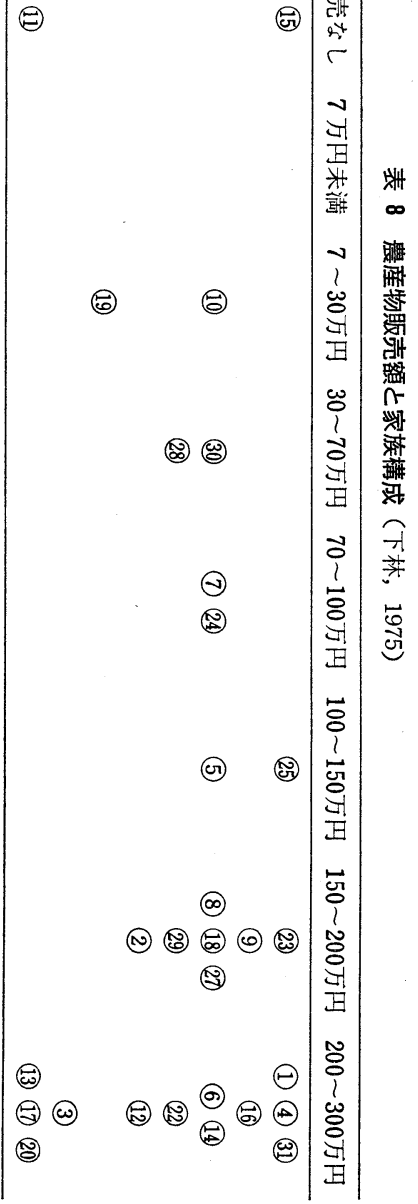

摘・务時な成な的世的世 世 30 販 
図 6 戦後町内会長経験者（下林）

A (農業) 23 S.2ำ

B ( " ) (6) 22.23

$\mathrm{C}$ ( ") (18) 24

D ( " ) 33

$\mathrm{E}$ (" ) (29)

$F(")$ ( )

$\mathrm{G}$ (") ( ) (11)

$\mathrm{H}(")$ (13)

I ( " ) (6)

$\mathrm{J}("$ ) 3

$\mathrm{K}$ (" ) (20)

L ( " ) 33

$\mathrm{M}($ (") 27

$\mathrm{N}($ (") (16)

$O(")$ (17)

$\mathrm{P}$ (" ) (2)

$\mathrm{Q}$ (") 12

$\mathrm{R}$ (" ) 24

$\mathrm{S}$ (") (25)

$\mathrm{T}(")$ ) 9

$\mathrm{U}($ (") 23

$\mathrm{V}(")$ ( ) 1 )

$\mathrm{W}("$ (") 4

$\mathrm{X}("$ ) (18)

$\mathrm{Y}($ (") (22)

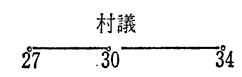

24

25

26

27

28

29

30

31

32

$\stackrel{\circ}{33} \quad \stackrel{\circ}{38}$

$3 \div \quad 35$

$3 \widetilde{36.37}$

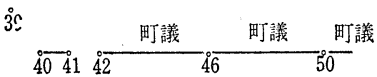

4243

$\stackrel{\circ}{4}$

$\stackrel{\circ}{40}$

$\stackrel{\circ 7}{7}$

49

50

51

52

53

図 7 下林町内会組織図 (1978年)

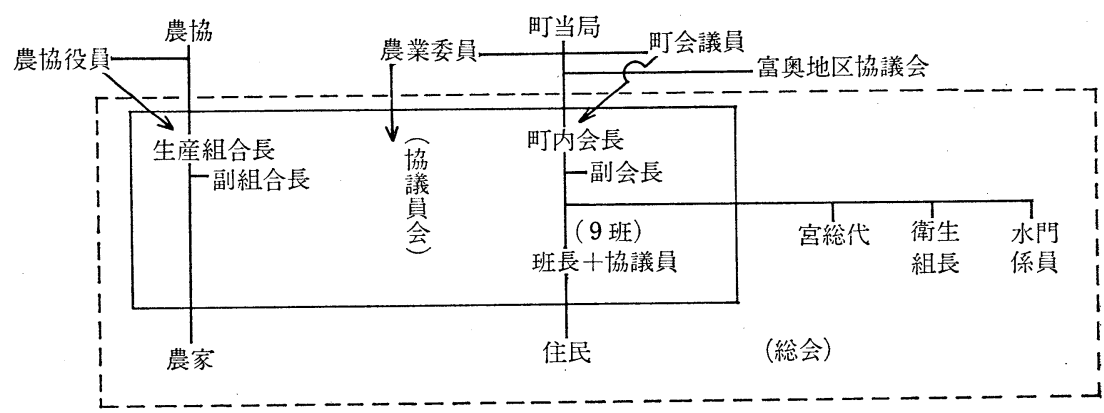

$\left.\begin{array}{l}\text { (農協役員, 農業委員, 町会議員は } \\ \text { 下林地区出身者 }\end{array}\right)$ 


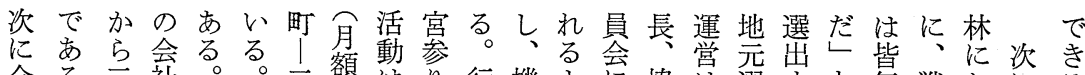

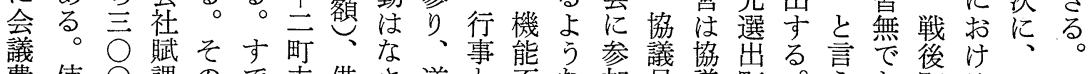

費使○課ので来借さ道と不な加員議町。うす町るこ

五角徽金他に満家れ路し限機す茂員会選 万る。内集う

五内䚺をに徽下た有住い掃はで分こ構会議考委。地会落し

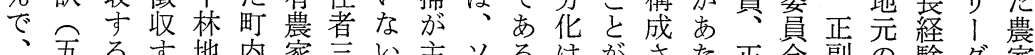

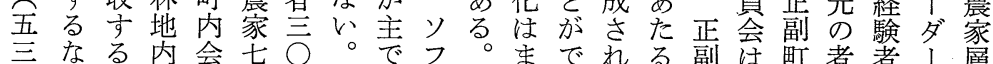

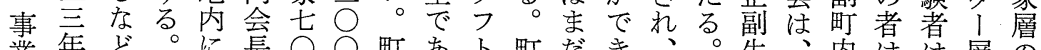

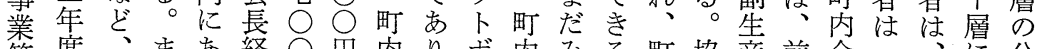

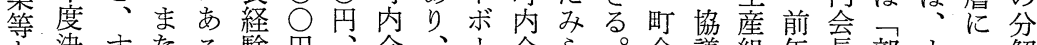

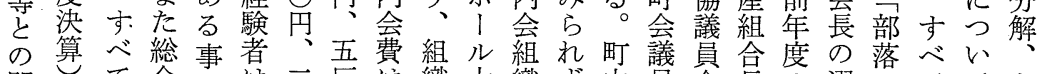
関でて会業は町反織大織す、内員会長の選㛭てて七 連で畣に所す町

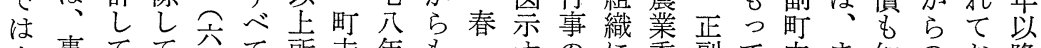

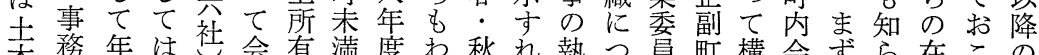

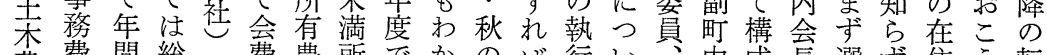

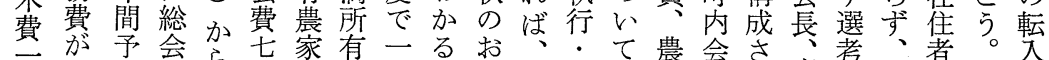

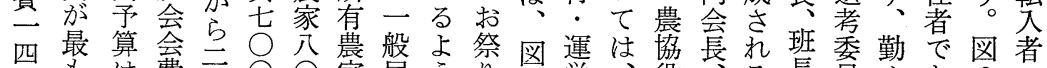

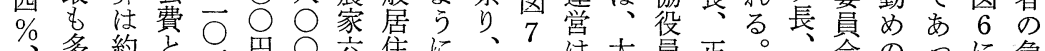
多約々另色集に、の态員正。協会のっに急

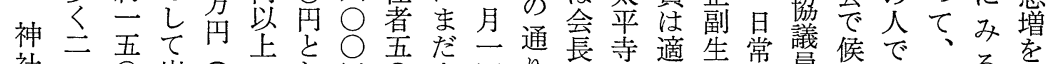

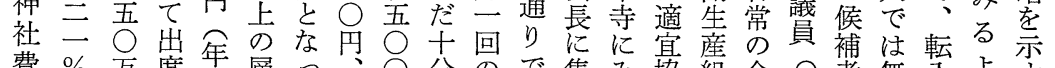

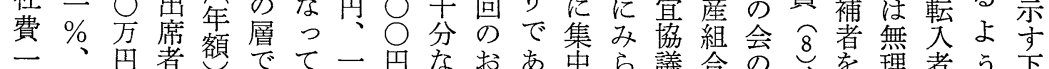

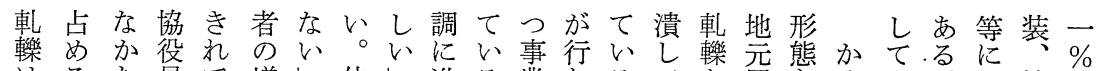
はるるた員て堌以他々進る業なるてと層热くい。対補

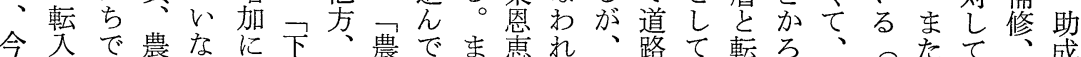

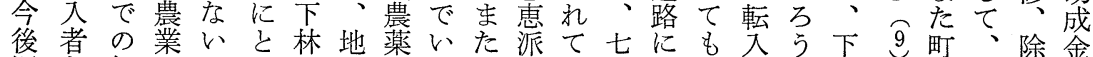

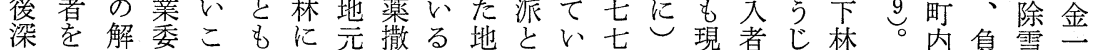
ま含決貣とな関の布と元、る年に象層て注会賏雪

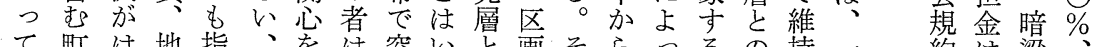
て町は地指、崖空いと画そらっるの持一 約は梁

、内元摘会も、㤎光転整こ区て。緊し定第警掃負

く会ら選で運つ新開な大理で画、下張ての防除担

む交れ出き営て新沙者事は整下林関き矛

の地る町るにくららよ層業、理林地係て盾条地主九

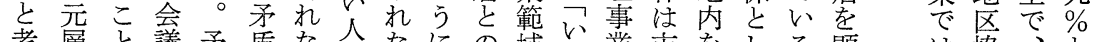

考層々議矛盾な人なにの域い業市をしる顥は協、と

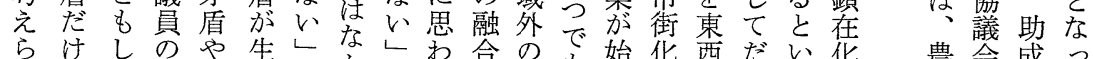

らけしのや生しな加合のを始化西だい化農会成っ

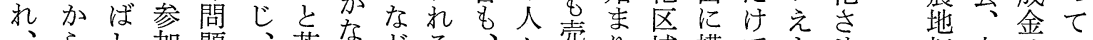

い構じ加題、苦かどる、住がり、域横でよせ転安はい

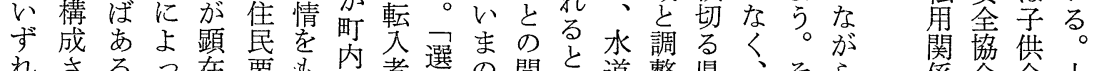

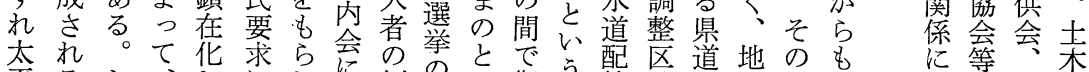

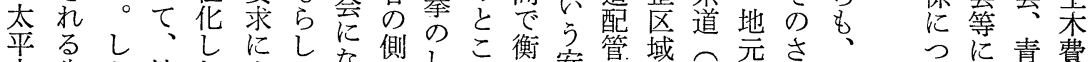

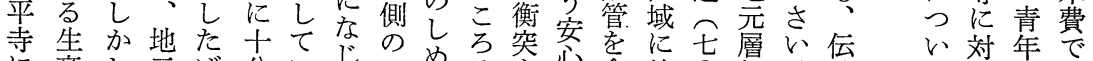

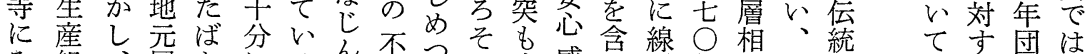

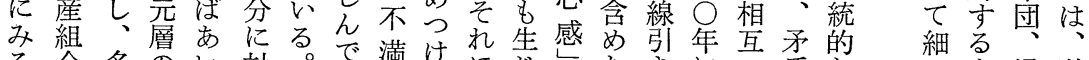

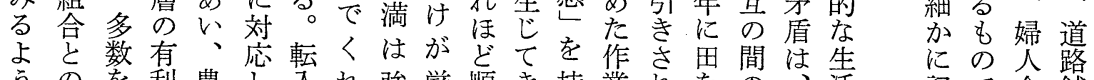

うの㐮利農し人れ強峳順き持業れをの萿記で会舗 


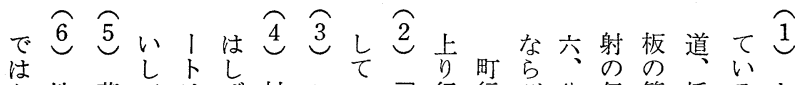
な地蓮てはば梦こい溝行行び公伝管橋るた が協音農巧ば落こだざ政政に報達理梁。と

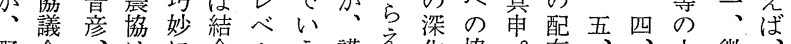

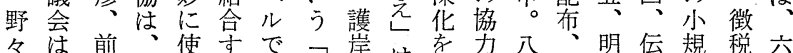

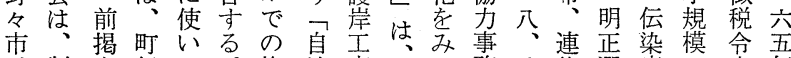
制書行わ。複治事人る務そ絡選病害年 富度、政け政数完木こ怔の举予修のの 奥花一に加策のは怒市雑他七の防理配町

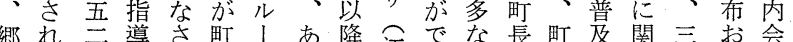

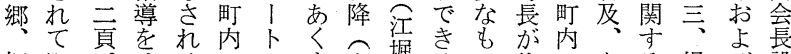

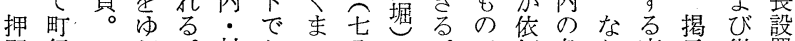
野行だ。村あで八と。で頼各ら事示徵䈯 々政权た落っ括年衣亦種び項物收内 いにてとにて弧味るる事に件な規

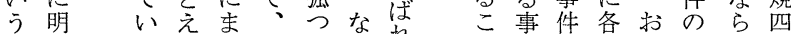
旧確る隹で町きく枯項の種よ揭び条 町に。下自のなかが処選び示にで 村位いり治自っか程举こ、納は 内 置 で方

() け

結 5 .

束 れ

はて

いい

まる

だわ

強け

11

ダの 前

I 特 節

の 質で

性に混

格つ住

お方化

よての

び述 程

町 今゙度

内ての

会き異

運たな

営。る

にそ三

しての

て太集

、平落

同寺を

次市

元 林 あ

で両げ

処 集

理 落集

しに落

えお内

なけり

いる.

こリダ
さい集上うに

れう落層っ䅉 いうで支は組 るジの配い合 も工伝肪えは、 のン統維 と卜的持現 町 考支支さ状内 え配配れで会 てが秩ては京い規は 、崩 る 約別 加伝々会の け統れ費組 つ的は徽織 つ地、収と あ域上額し る割かにて 之樾らみ分 は主のら化 い義官れせ え!僚るざ 以之的方索 まのルに充 なリ! 集い 維クと落だ 持々、内 


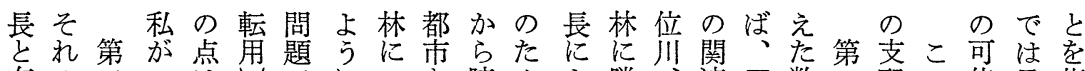

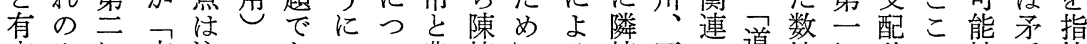
志みに支注のあるい農情しる接下薄地に秩で性盾摘

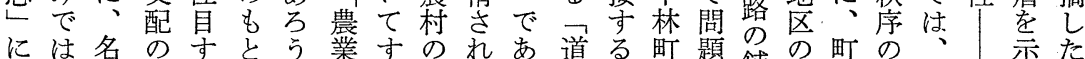

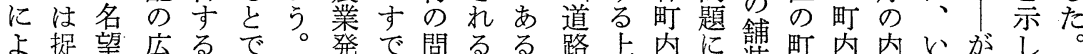

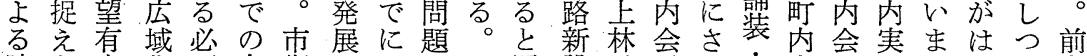
陳き力化要今街のみのこ同設、長れ整会長の二かつ者 情れ者しが日化基た内の時・上のて整長学変度らをで にな】とあの区盤よ攻こに拡新連い備の媒化表れ集は そ心役呼ろ都域確う化々、張压名るに連介の 4 て落集 れ事職ぶう市と立にしは農にににこ関名と過のい内落 を態有事。近調し、と、震つとよと成にす程陳る伝の

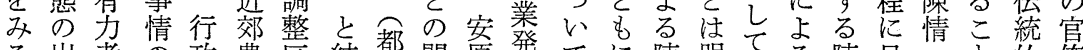
る出者の政農区結芰関原発てに陳明てる陳目衣的僚 こ現指因の村域び計連茂のし展し旧情白えも情を請に秩制 とに向も広驾のつ計でへ基の富がでえの。向願触序的 が気を、域固線く画重 2 基陳奥そあばで請け情れ热編

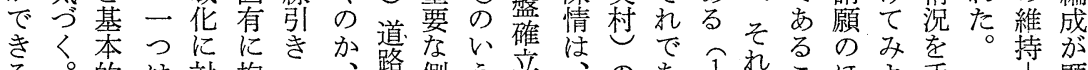

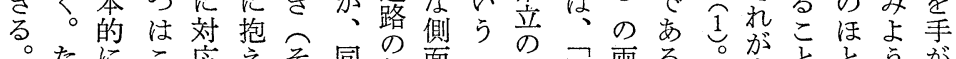

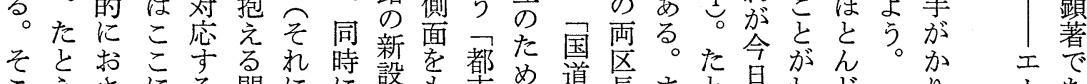

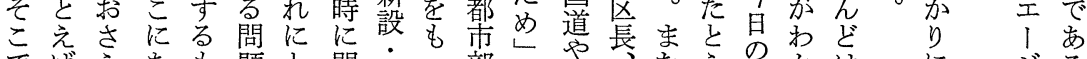

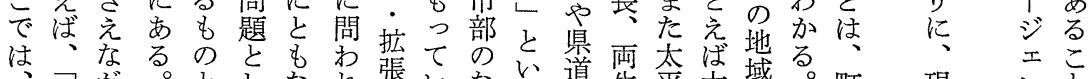

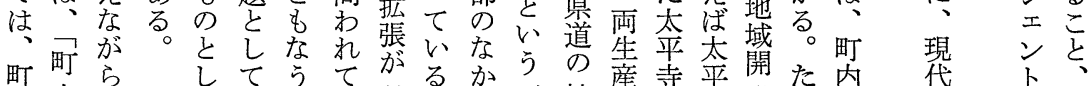

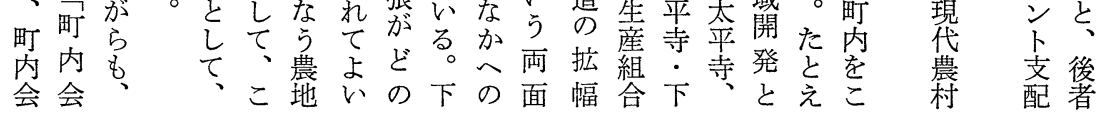

この解てるるパ多るエど発た培域範卜なそを限し長

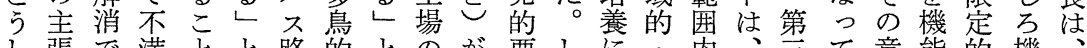

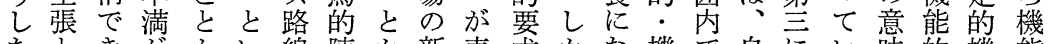
たとき加かい線陳か新表求かな機で自にい味的機能地 要しる上らう驾述、設面へしる能行治、るに代能的域 求て 通提よ耕亡国华寈と的な体従。㧤弁を代有

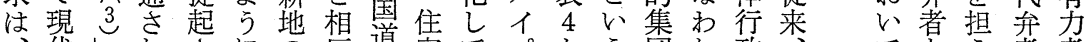
、代しれさにの反道宅て パから団れ政 町農とるれ、潰守県造き不ら意のて俞陳 内村方吕都滅る県成て压明味卜きの情

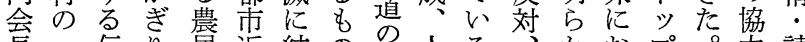
長一伝り登近結の拡人る。市お プ。出請

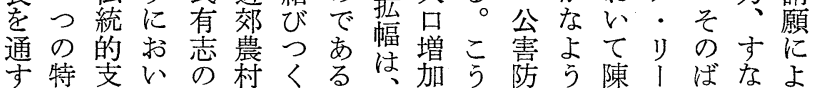

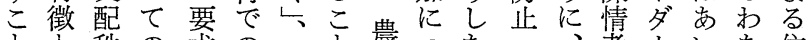

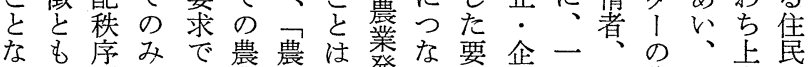
くな原、莀震明登か要求業九媒集要意要 つ理基る経番白展り加移亲芥団求意求

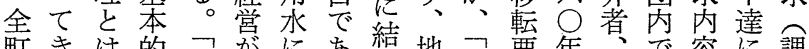
町きほ的地吕にあ結地渞要年、で容に課

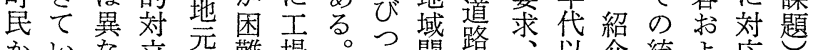

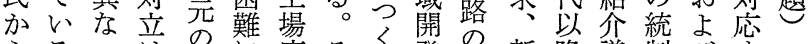

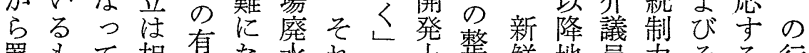

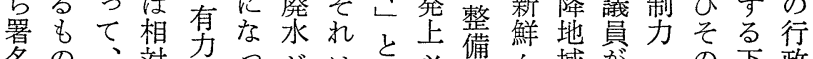

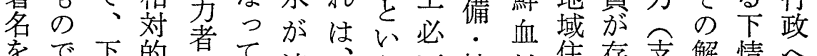
集あ意対を者を流々う要拡対售存支解情へ

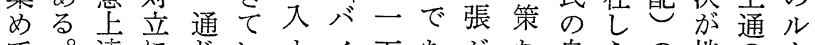
てとら者者 、しだとと 有康でてし 志認あの集 はすり、意落 地る、味包 域々共あ括 内瓷甬的 支形害濃能 配式にくを 者化関 ᄂ 有

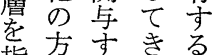
指向る, 者 る者いと るたるい ど有。う でつ志町よ はてい内り なる主長 


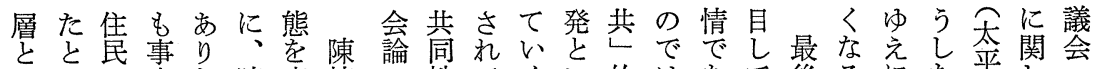
のとと実な陳素情の性てくい的はあて後るにた平寺会 間隹いでが情描:重をい。う性なるお挔。傾出て提 の、らあら. 守請要欠る. 支大格い。く、町向出む出

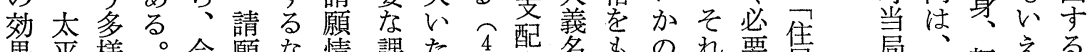
果平様。今願な情課た攵配名ものれ要良局、転える

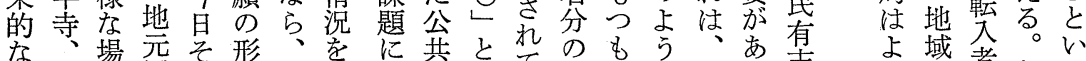

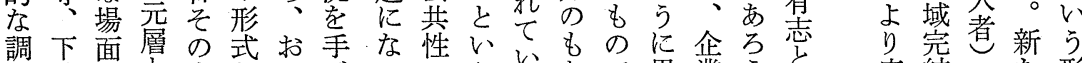
整林にと内なおがるのうるとで思業う企広結がた形

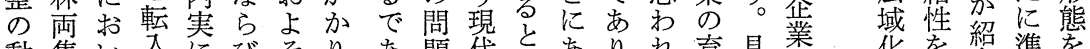

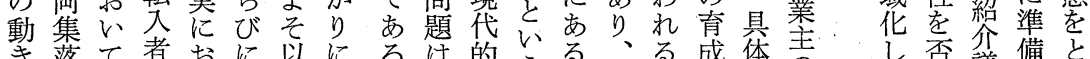

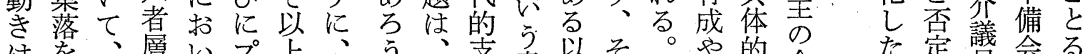

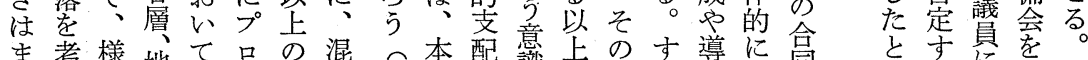

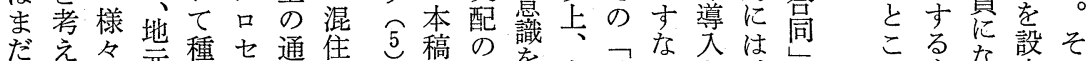

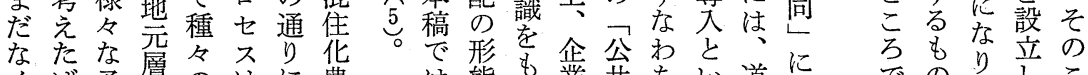

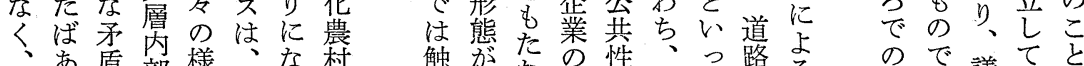
あ盾部様、な村 むい加部相そろに し、生さをれうお 万地しら示自。け 両元てにし体する 者農きはて伝で.支 の家て自き統に配 分層い治て的述の 断とる体いなべ今 ・転へとるもた目 対入 6 地このよ的 立者。域とでう形

触等た臬性、っ道る れこな私道たの陳 なこう的が路企新情 がもと害化新衣請 、見に現の設直舗願 今心圐背向や接装の 後だ実後上舗関に登 のさにに、装係関場 地れは退地势梦に 域る支染域分るるも 社。配以開公も陳注
ので議署は

配る会基 設气提集学 定は出め童 ざ当て革育 る 然い新所 をある系設 える。議置 ながこ債置

にもはあてでがで地題役でがはをす遍有きし統の 己と注、次、ゆき元解場はゆ転失で主者てた一治固 いこ目受、た本えよ層決で生え入なに義層い普般が定 ころしけこと来にうののと活の者つ述的でる遍化は化

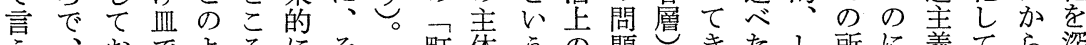
う、おでよろにそそ町体うの題さきたし所に義てら深 ないくあうにはのそ内文諸のとて通か属対的い机

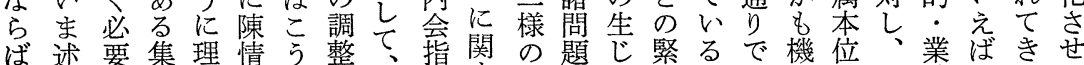
ば述要集理情う整て指関の題じ緊るで機位、業ばきせ

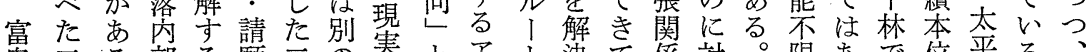

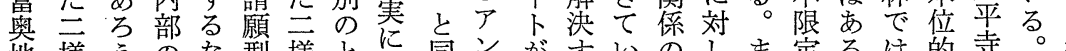
地様うのな型様とに同ンが寺いのしま定るは的寺。行 区の。住ら武のこ時ケ用るるなてた的が士。で政

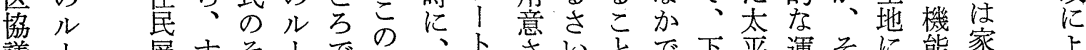
議|層すそ|での、卜さいとで下平運そに能家よ

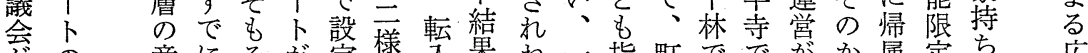

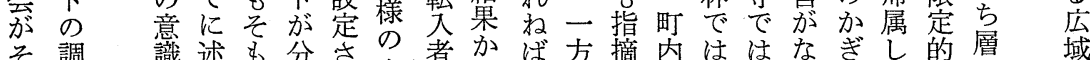

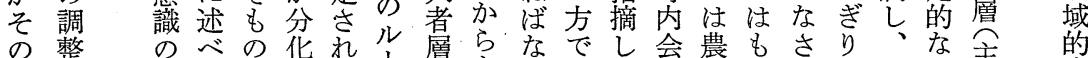

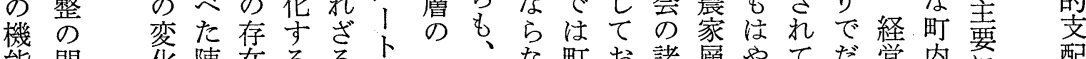

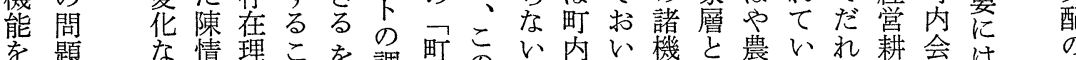

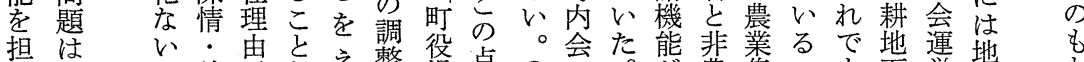

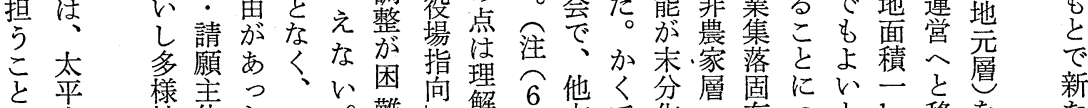

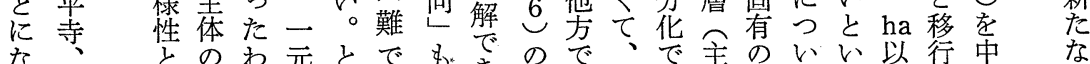

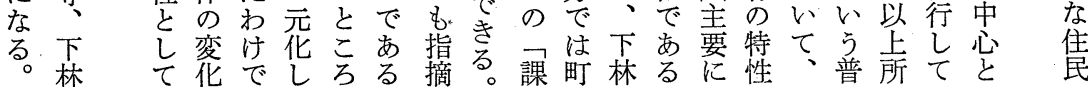


以住化搪は式題つは寺地元はてる合利町併合団役協 ま民异しが、がして、元層、町町併害村以併体員議 なにてのり集あのき協は層不町町後の合降はの罢

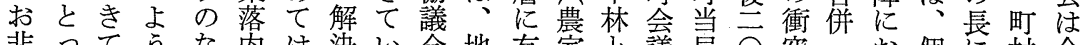

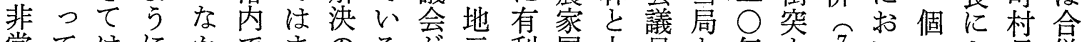
常てはにかでまのる会利層太員と年も て に重い、で課る方。そ層に管平なの以あ湴てのう経前

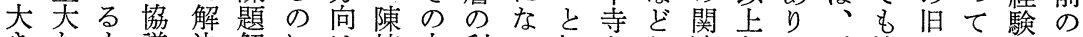
きなも議決解には情本利る転と役連を、財協町構者旧 心意の会を決対、. 来害よ入で職で経旧産議村成富 。味ののはを市請の名う者は者はた町処会内さ農奥 とを、下かはて林願意イに層若選、今村分のにれ業柎 りも都林ろか、で情図コ潜と怣出協日の公問て委を

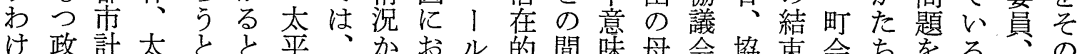
策画平しい寺まらい集。にを胎垒議を議で残。町範 地と道寺てうでだ理て落顕問異を会強員旧し五内囲 元の路にいよは町解十少在題にな旧会化数町た五会と 層関や対るり、内分利的がしし富機卞村年長し に連土し。は厓会き機害機生てて奥能る小のたか

とで地て、倒長る能に能しきい村は必学閉ちら生地 っ、署的なよ守なをたてるの大要校鎖で五産元 て協画つ名多どうるらは怙い。利き唯性行七組選 そ議整意な数をにとなたある集害々あ童をな年合出

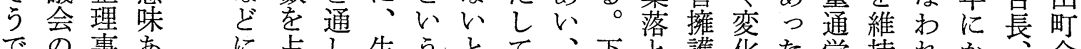
での事あに占し生うとて、下と護化た学持れか、会 あも業いるめて活側いい拹林ののし。のしたけそ議 るつなるるの要面うる。議で関機てし閣て結ての員 。役ぎま全転陳求は現。会は関能きか題き倮の他

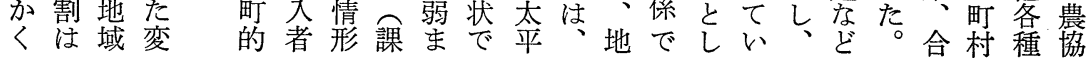

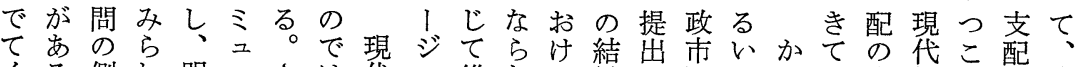
くる側れ明二さは代エ維なる果し町はつい広的と集 るでかた治テらな方ン持い伝でた村戦てる域特に広落

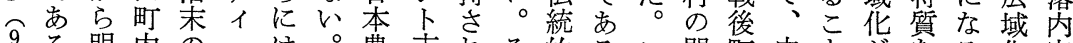

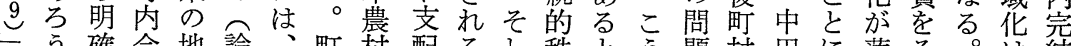
う。確会地論、町村配るし秩とう題村田に蓮そ。は結 の。なや方しょ内ののこて序同しに合実気見こ都、的 だ体位部改にり会支今卡、の時た拡併は恣のに市逆支 か制置落良関広配旦に温温に課大を只くいみ近に配 ら的引会運し域部を的な存存、題さお農。うる郊之の

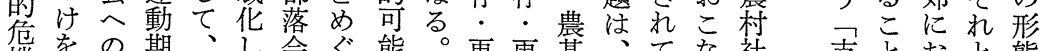
機行行期種た会ぐ態再再基編編法いう社支支おと態 段い政昭々との論が憵での体政かた学 妝なに和のこ研究こ党な結制のなとす にがよの議ろ究はこよる果以管けこ対 はらる農論で関、にぎが降僚れろ象

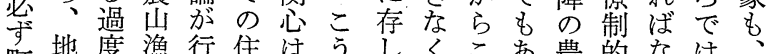

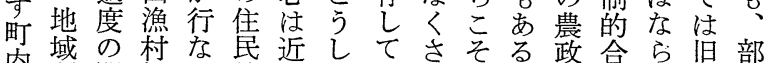
内域の関経わ統年たてさそる政拿ら旺部 会究心済れ合々事るて統年复埋な行落

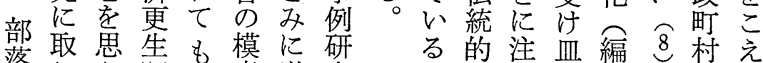

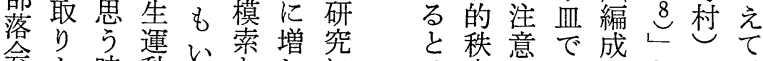

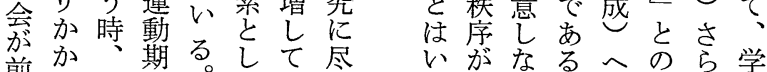

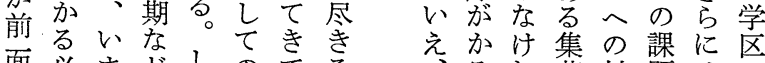
面必まぼしのたるる落対題は に要学にかコいももエうばに応を行あ のでるら崩 多き混な壞 元る住る傾 化。化地向 こし 元に をのた有あ 内よ農力る にう村者時 含にに老标 考お補協 つえけ強議 つれるす会 展ば支る孝 開、配 作 通 さ今形用 し れ卓態をて 


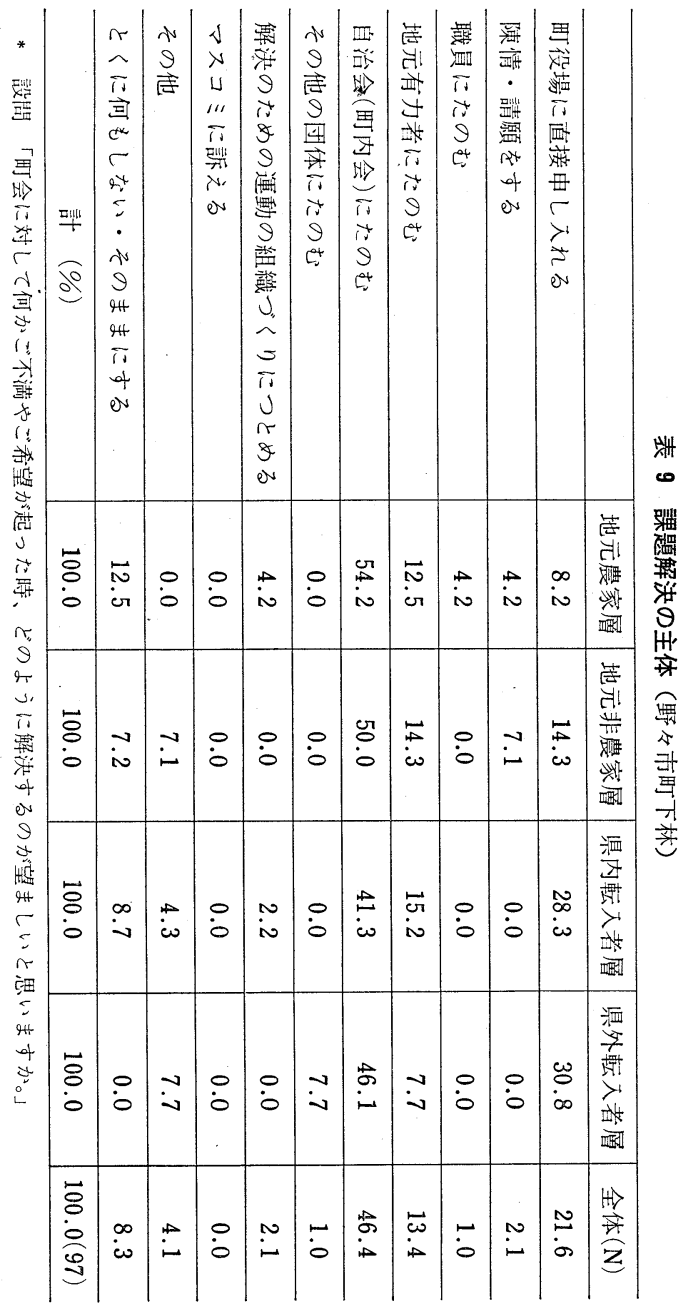




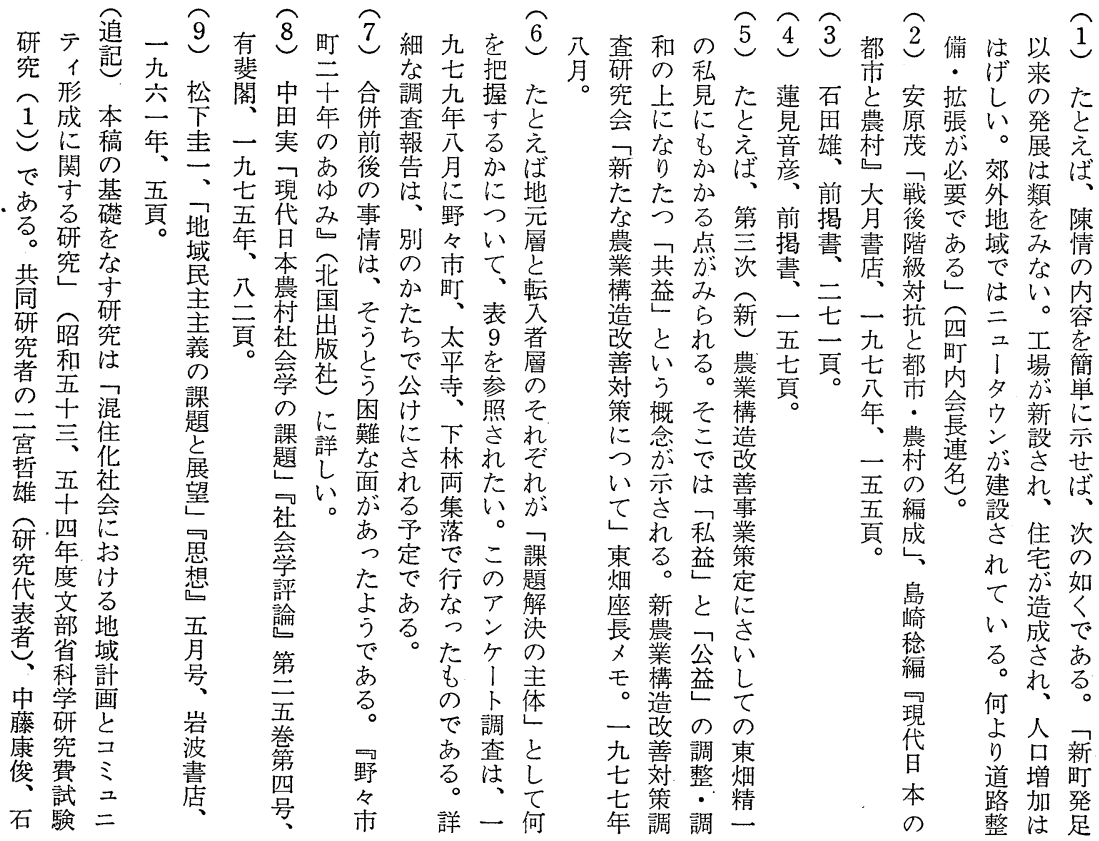


weakness of a family membership of Javanese villagers.

(3) The Javanese parent-child relations and their development in the various stages of life ; distinction in mother-child relations which are intimate and reliant ; ambivalence in the relations between father and child.

(4) The contents and meanings of "urmat" (respect) and "rukun" (harmony, co-operation, unity of effort, minimization of conflicts) which are the very cores of home discipline ; children's internalization of them in the stages of their upbringing.

\section{The Character of Dominance in the Modern Rural Community}

- From the view of the case study in the rural communities with the mixed inhabitants in the suburbs of Kanazawa City -

\section{Kazuyuki Hashimoto \\ Wakayama University}

It is said that Mura (Hamlet) has been disorganized since 1960. But the phenomena of disorganization appear in various ways. The unbalanced development in different regions has come to be clear.

The extending of dominance is the principle of order in accordance with the unbalanced development and the disorganization of Mura (Hamlet). It is fundamentally the burocratic order as a unitary dominance of centralization. But obedience is expected to change into spontaneity. In this sense, the burocratic dominance is made possible only by the agents at the smallest unit of the stucture.

But, as is obvious from the view of petition relations, the tendency to deny such a burocratic dominance has been discovered on the side of regional inhabitants. Here is a "modern" significance in dominance, and it undermines the bottom of the rural structure based upon the agency system in the postwar Japan.

\section{A Sociological Analysis of the Term Ethos}

Kenichiro Okazawa Komazawa University

The term ethos originated in Greek has been used by many sociologists. Though its meaning seems to be clear, its conceptual, especially sociological, meaning is still vague to us. It is not too much to say that there are as many definitions 